\title{
Inorganic \& organic materials for rechargeable Li batteries with multi-electron reaction
}

\author{
Kai Zhang, Zhe Hu, Zhanliang Tao and Jun Chen*
}

Rechargeable Li batteries as electrochemical energy storage and conversion devices are continuously changing human life. In order to meet the increasing demand for energy and power density, it is essential and urgent to exploit the electrode materials with high capacity and fast charge transfer (for Li-ion and Li-S batteries) and electrocatalysts with high activity (for rechargeable $\mathrm{Li}-\mathrm{O}_{2}$ batteries). The high capacity is attributed to high electron transfer number and low molecular weight of the electrode materials. Combined with proper nanostructure design, the electronic transfer and ionic conductivity will be improved. This review summarizes recent efforts to apply electrode materials for Li-ion batteries with multi-electron reaction, $\mathrm{Li}-\mathrm{S}$ batteries, and efficient electrocatalysts for $\mathrm{Li}-\mathrm{O}_{2}$ batteries. The methods to enhance the cycling and rate performance have been discussed in detail. Advanced rechargeable Li batteries with multi-electron reaction will become the research emphasis in the future.

\section{INTRODUCTION}

In modern society, electrochemical energy storage and conversion (EESC) devices have been applied in many fields such as consumer electronics, smart electricity grid, medical treatment, aerospace, and electric vehicles [1-6]. Among various EESC devices, rechargeable batteries with Li chemistry have received wide attention and undergone fast development during the last four decades because of their high operation potential and energy density, light mass, long life, high-rate capability, and environmental friendliness $[7,8]$. Since Li-ion batteries (LIBs) were commercialized in the early 1990s, our life has been considerably changed. However, traditional LIBs with $\mathrm{LiCoO}_{2} /$ graphite couple can hardly meet the increasing requirements for the life time of the devices. It is necessary and urgent to exploit novel Li-host materials with high specific energy.

The specific energy is equal to the product of electromotive force $(E)$ and specific capacity $(Q)$. According to thermodynamics, $E$ and $Q$ obey the equations as follows [5]:

$$
\begin{aligned}
& \Delta G=-n E F, \\
& Q=\frac{n F}{3.6 M_{\mathrm{w}}},
\end{aligned}
$$

where $\Delta G$ is the Gibbs free energy difference, $n$ the transfer electron number, $F$ the Faraday constant, $M_{\mathrm{w}}$ the molecular weight. It is very important to choose the electrode materials with high specific capacity and suitable voltage. The high specific capacity is attributed to high transfer electron number and low molecular weight.

Fig. 1 shows the discharge curves of representative cathode materials and the charge curves of representative anode materials of LIBs. For anode materials, the capacity is relatively high except for spinel $\mathrm{Li}_{4} \mathrm{Ti}_{5} \mathrm{O}_{12}$ with large molecular weight. However, as to cathode materials, only
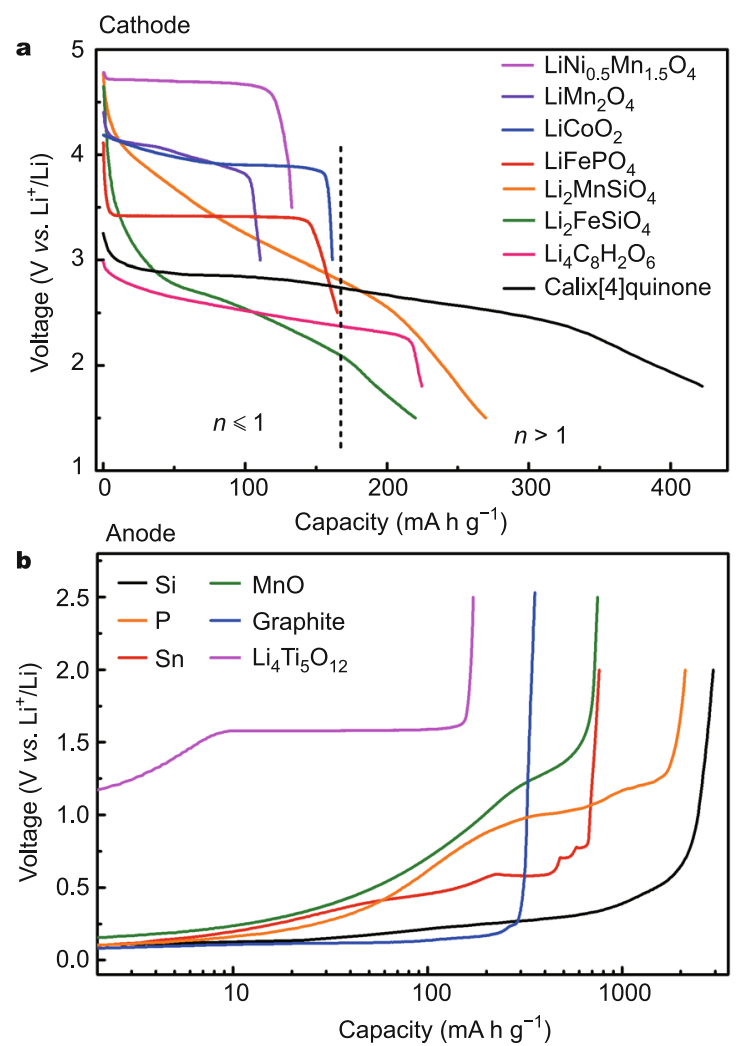

Figure 1 (a) Discharge curves of representative cathode materials and (b) charge curves of representative anode materials of LIBs.

Key Laboratory of Advanced Energy Materials Chemistry (Ministry of Education), College of Chemistry, Collaborative Innovation Center of Chemical Science and Engineering, Nankai University, Tianjin 300071, China

*Corresponding author (email: chenabc@nankai.edu.cn) 
some polyanion-type compounds and organic compounds can achieve the multi-electron reaction. Cathode materials have become a bottleneck for the development of LIBs. It is difficult to obtain a specific energy of more than 300 $\mathrm{W} \mathrm{h} \mathrm{kg}{ }^{-1}$ for present LIBs.

Recently, $\mathrm{Li}-\mathrm{S}$ and $\mathrm{Li}-\mathrm{O}_{2}$ batteries have received intense interest owing to their theoretical specific energy of more than $2500 \mathrm{~W} \mathrm{~h} \mathrm{~kg}^{-1}$ [9]. $\mathrm{S}$ and $\mathrm{O}_{2}$ can react with $\mathrm{Li}$ via a two-electron reaction to form $\mathrm{Li}_{2} \mathrm{~S}$ and $\mathrm{Li}_{2} \mathrm{O}_{2}$, respectively. Nevertheless, the sluggish kinetics and poor cyclability limit their commercial step. Table 1 summarizes the electrochemical reaction, potential, transfer electron number, theoretical specific capacity, and practical capacity of the representative electrode materials of Li secondary (rechargeable) batteries. The research direction of Li secondary batteries should focus on advanced inorganic LIBs with silicate $/ \mathrm{Li}_{2} \mathrm{~S}$ cathode and $\mathrm{Sn} / \mathrm{Si}$ anode, organic LIBs with carbonyl compounds, Li-S batteries with optimal electrodes and electrolytes, and $\mathrm{Li}-\mathrm{O}_{2}$ batteries with highly active catalysts in the future.

Besides the specific energy, the specific power and cyclability are also important parameters for evaluating the electrochemical performance. To achieve the high-rate capability and long-term cyclability, methods like nanosizing (e.g., nanoparticles, nanorods, nanosheets, and nanopores),

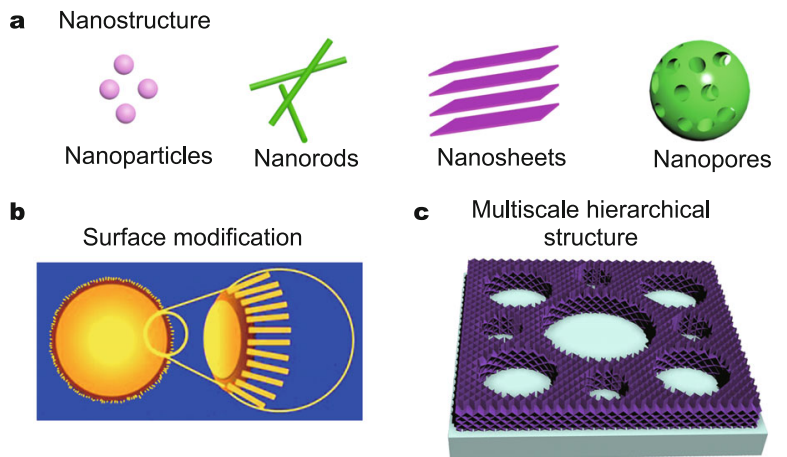

Figure 2 Schematic illustration of main strategies to improve the electrochemical performance. (a) Preparing various nanostructures (e.g., nanoparticles, nanorods, nanosheets, and nanopores), (b) surface modification, and (c) designing the multiscale hierarchical structure for electrode materials and current collectors.

surface modification, and preparing multiscale hierarchical structure are attempted (Fig. 2). Decreasing the particle size can not only enhance the utilization of active materials, but also promote the kinetics of the electrochemical reactions. In general, the diffusion time $(\tau)$ is proportional to the square of the diffusion length $(L)$ like Equation (3) [10]:

$$
\tau=\frac{L^{2}}{D_{\mathrm{Li}}}
$$

Table 1 Electrochemical reaction, potential, transfer electron number, theoretical specific capacity, and practical capacity of the representative electrode materials of Li secondary batteries

\begin{tabular}{|c|c|c|c|c|c|c|c|}
\hline & Electrode materials & Electrochemical reaction & Potential (V) & $\mathrm{TEN}^{\mathrm{a}}$ & $\begin{array}{l}\text { Theoretic SC } \\
\left(\mathrm{mA} \mathrm{h}^{-1}\right)\end{array}$ & $\begin{array}{c}\text { Practical SC } \\
\left(\mathrm{mA} \mathrm{h} \mathrm{g}^{-1}\right)\end{array}$ & Ref. \\
\hline \multirow{2}{*}{ Li metal batteries } & $\mathrm{FeS}_{2}$ & $\mathrm{FeS}_{2}+4 \mathrm{Li}^{+}+4 \mathrm{e}^{-} \leftrightarrow \mathrm{Fe}+2 \mathrm{Li}_{2} \mathrm{~S}$ & 1.5 & 4 & 894 & $\sim 560$ & {$[11]$} \\
\hline & S & $\mathrm{S}+2 \mathrm{Li}^{+}+2 \mathrm{e}^{-} \leftrightarrow \mathrm{Li}_{2} \mathrm{~S}$ & 2.2 & 2 & 1,675 & $\sim 1,100$ & {$[12]$} \\
\hline \multirow{9}{*}{$\begin{array}{l}\text { Inorganic } \\
\text { Li-ion batteries }\end{array}$} & $\mathrm{Li}_{3} \mathrm{~V}_{2}\left(\mathrm{PO}_{4}\right)_{3}$ & $\mathrm{Li}_{3} \mathrm{~V}_{2}\left(\mathrm{PO}_{4}\right)_{3} \leftrightarrow \mathrm{V}_{2}\left(\mathrm{PO}_{4}\right)_{3}+3 \mathrm{Li}^{+}+3 \mathrm{e}^{-}$ & $3.5 / 3.6 / 4.0$ & 3 & 197 & $\sim 160$ & [13] \\
\hline & $\mathrm{Li}_{2} \mathrm{FeSiO}_{4}$ & $\mathrm{Li}_{2} \mathrm{FeSiO}_{4} \leftrightarrow \mathrm{FeSiO}_{4}+2 \mathrm{Li}^{+}+2 \mathrm{e}^{-}$ & $2.8 / 4.8$ & 2 & 332 & $\sim 200$ & {$[14,15]$} \\
\hline & $\mathrm{Li}_{2} \mathrm{MnSiO}_{4}$ & $\mathrm{Li}_{2} \mathrm{MnSiO}_{4} \leftrightarrow \mathrm{MnSiO}_{4}+2 \mathrm{Li}^{+}+2 \mathrm{e}^{-}$ & $4.1 / 4.5$ & 2 & 333 & $\sim 280$ & {$[14,16]$} \\
\hline & $\mathrm{Li}_{2} \mathrm{~S}$ & $\mathrm{Li}_{2} \mathrm{~S} \leftrightarrow \mathrm{S}+2 \mathrm{Li}^{+}+2 \mathrm{e}^{-}$ & 1.7 & 2 & 1,166 & $\sim 800$ & {$[17]$} \\
\hline & Sn & $\mathrm{Sn}+4.4 \mathrm{Li}^{+}+4.4 \mathrm{e}^{-} \leftrightarrow \mathrm{Li}_{4.4} \mathrm{Sn}$ & 0.6 & 4.4 & 990 & $\sim 700$ & {$[18]$} \\
\hline & $\mathrm{Si}$ & $\mathrm{Si}+4.4 \mathrm{Li}^{+}+4.4 \mathrm{e}^{-} \leftrightarrow \mathrm{Li}_{4.4} \mathrm{Si}$ & 0.4 & 4.4 & 4,200 & $\sim 3,000$ & {$[19,20]$} \\
\hline & $\mathrm{P}$ & $\mathrm{P}+3 \mathrm{Li}^{+}+3 \mathrm{e}^{-} \leftrightarrow \mathrm{Li}_{3} \mathrm{P}$ & 1.0 & 3 & 2,595 & $\sim 2,000$ & {$[21]$} \\
\hline & $\mathrm{Fe}_{2} \mathrm{O}_{3}$ & $\mathrm{Fe}_{2} \mathrm{O}_{3}+6 \mathrm{Li}^{+}+6 \mathrm{e}^{-} \leftrightarrow 2 \mathrm{Fe}+3 \mathrm{Li}_{2} \mathrm{O}$ & 1.5 & 6 & 1,007 & $\sim 900$ & {$[22,23]$} \\
\hline & $\mathrm{Li}_{4} \mathrm{Ti}_{5} \mathrm{O}_{12}$ & $\mathrm{Li}_{4} \mathrm{Ti}_{5} \mathrm{O}_{12}+3 \mathrm{Li}^{+}+3 \mathrm{e}^{-} \leftrightarrow \mathrm{Li}_{7} \mathrm{Ti}_{5} \mathrm{O}_{12}$ & 1.55 & 3 & 175 & $\sim 170$ & {$[24]$} \\
\hline \multirow{4}{*}{$\begin{array}{l}\text { Organic Li-ion } \\
\text { batteries }\end{array}$} & \multirow{2}{*}{$\mathrm{Li}_{4} \mathrm{C}_{8} \mathrm{H}_{2} \mathrm{O}_{6}\left(\mathrm{Li}_{4} \mathrm{DHTPA}\right)$} & $\mathrm{Li}_{4} \mathrm{C}_{8} \mathrm{H}_{2} \mathrm{O}_{6} \leftrightarrow \mathrm{Li}_{2} \mathrm{C}_{8} \mathrm{H}_{2} \mathrm{O}_{6}+2 \mathrm{Li}^{+}+2 \mathrm{e}^{-}$ & 2.6 & 2 & 242 & $\sim 220$ & {$[25]$} \\
\hline & & $\mathrm{Li}_{4} \mathrm{C}_{8} \mathrm{H}_{2} \mathrm{O}_{6}+2 \mathrm{Li}^{+}+2 \mathrm{e}^{-} \leftrightarrow \mathrm{Li}_{6} \mathrm{C}_{8} \mathrm{H}_{2} \mathrm{O}_{6}$ & 0.8 & 2 & 242 & $\sim 240$ & {$[25]$} \\
\hline & $\mathrm{C}_{16} \mathrm{H}_{6} \mathrm{O}_{4}(\mathrm{PTO})$ & $\mathrm{C}_{16} \mathrm{H}_{6} \mathrm{O}_{4}+4 \mathrm{Li}^{+}+4 \mathrm{e}^{-} \leftrightarrow \mathrm{Li}_{4} \mathrm{C}_{16} \mathrm{H}_{6} \mathrm{O}_{4}$ & 2.59 & 4 & 409 & $\sim 360$ & {$[26]$} \\
\hline & $\mathrm{C}_{28} \mathrm{H}_{16} \mathrm{O}_{8}(\mathrm{C} 4 \mathrm{Q})$ & $\mathrm{C}_{28} \mathrm{H}_{16} \mathrm{O}_{8}+8 \mathrm{Li}^{+}+8 \mathrm{e}^{-} \leftrightarrow \mathrm{Li}_{8} \mathrm{C}_{28} \mathrm{H}_{16} \mathrm{O}_{8}$ & 2.7 & 8 & 446 & $\sim 380$ & {$[27]$} \\
\hline $\mathrm{Li}-\mathrm{O}_{2}$ batteries & $\mathrm{O}_{2}$ & $2 \mathrm{Li}+\mathrm{O}_{2} \leftrightarrow \mathrm{Li}_{2} \mathrm{O}_{2}$ & 2.7 & 2 & 1,675 & - & {$[28]$} \\
\hline
\end{tabular}

a) TEN: transfer electron number; b) SC: specific capacity. 
For similar $\mathrm{Li}^{+}$diffusion coefficient $\left(D_{\mathrm{Li}}\right)$, when the diffusion length is changed from $1 \mu \mathrm{m}$ to $10 \mathrm{~nm}$, the diffusion time can be reduced by four orders. Furthermore, the porous structure facilitates the accommodation of volume expansion and the infiltration of the electrolyte. Surface modification is also an effective strategy to maintain the structural stability and adjust the reaction interface. However, nanostructure is a double-edged sword, and it also suffers from the disadvantages of low tap density, undesirable side reactions, and complex synthetic method [10]. Low tap density leads to low volumetric specific capacity and specific energy, and high activity of nanomaterials may induce some side reactions such as the decomposition of the electrolyte, resulting in poor cycling performance. The synthetic method of nanomaterials is complex compared with the solid-state method, so it is difficult to meet the commercial requirements. Preparing the multiscale hierarchical structure is conducive to combine the advantages of nanomaterials and bulk materials, which improves the volumetric energy density and maintains the high performance at the same time.

In this review, recent studies about inorganic/organic electrode materials for LIBs with multi-electron reaction, Li-S batteries, and $\mathrm{Li}_{-} \mathrm{O}_{2}$ batteries are summarized. The strategies to improve the electrochemical performance are discussed in detail. The challenges and perspectives of multi-electron reaction are also proposed.

\section{Li-ION BATTERIES}

For cathode materials of LIBs, the layered $\mathrm{LiCoO}_{2}$, spinel $\mathrm{LiMn}_{2} \mathrm{O}_{4}$, and olivine $\mathrm{LiFePO}_{4}$ allow reversible extraction/ insertion of $0.5,1$ and 1 lithium per formula unit, respectively, which suffers from low capacity of less than 200 $\mathrm{mA} \mathrm{h} \mathrm{g}^{-1}$ [3]. Exploiting cathodes with high capacity is urgent. As to anodes of LIBs, most inorganic anode materials suffer from huge volume change, leading to poor cycling performance. Nanostructured anode materials can improve the electrochemical performance. Recently, organic LIBs have attracted much attention because of the high electron transfer number and low molecular weight of organic compounds. Nevertheless, the low conductivity and dissolution in organic electrolytes limit their development. In the following content, we will introduce the strategies to promote these electrode materials in detail.

\section{Inorganic cathode materials}

Among various inorganic cathode materials, polyanionic compounds such as $\mathrm{Li}_{2} \mathrm{MSiO}_{4}(\mathrm{M}=\mathrm{Fe}, \mathrm{Mn})$ and $\mathrm{Li}_{3} \mathrm{~V}_{2}\left(\mathrm{PO}_{4}\right)_{3}$ have attracted large attention mainly because of their high discharge capacity. The metal elements usually have viable oxidation states (e.g., $\mathrm{Fe}^{2+} / \mathrm{Fe}^{3+} / \mathrm{Fe}^{4+}, \mathrm{Mn}^{2+} / \mathrm{Mn}^{3+} / \mathrm{Mn}^{4+}$, and $\left.\mathrm{V}^{3+} / \mathrm{V}^{4+} / \mathrm{V}^{5+}\right)$, leading to multi-electron reaction during the charge and discharge processes.

$\mathrm{Li}_{2} \mathrm{FeSiO}_{4}$

$\mathrm{Li}_{2} \mathrm{FeSiO}_{4}$ (LFSO) is environmentally friendly and cheap, and has the ability to manage two-electron reaction with a theoretical specific capacity of $332 \mathrm{~mA} \mathrm{~h} \mathrm{~g}^{-1}$. As shown in Figs $3 a-c$, the crystal structures of LFSO are similar to $\mathrm{Li}_{3} \mathrm{PO}_{4}$ and are mainly classified into three space groups: $\mathrm{P} 2_{1} / \mathrm{n}, \mathrm{Pmn} 2_{1}$, and Pmnb [14]. All the crystal structures possess tetrahedral unit like $\mathrm{FeO}_{4}, \mathrm{LiO}_{4}$, and $\mathrm{SiO}_{4}$. In 2005, Nytén et al. [29] first reported that orthorhombic LFSO with Pmn2 space group provided one-electron reaction at $3.1 \mathrm{~V}$ in the first cycle. The Pmn2 ${ }_{1}$ phase has a $\beta-\mathrm{Li}_{3} \mathrm{PO}_{4}$ based structure, in which oxygen arrays form a slightly distorted hexagonal close-packed (hcp) structure and all the cations occupy half of the tetrahedral sites to form a corner-sharing network of tetrahedra (Fig. 3a). Masquelier's group [30] first prepared orthorhombic LFSO with Pmnb space group, in which the cations in the (001) plane form a succession of $\mathrm{FeO}_{4} / \mathrm{SiO}_{4}$ with opposite directions along the $a$ axis and $\mathrm{LiO}_{4}$ pointed in the same direction along the $a$ axis (Fig. 3b). For monoclinic $\mathrm{P} 2 / \mathrm{n}$ phase (Fig. $3 \mathrm{c}$ ), two edges are shared between $\mathrm{FeO}_{4}$ and $\mathrm{LiO}_{4}$, and the interlocked corner-shared $\mathrm{FeO}_{4}$ and $\mathrm{SiO}_{4}$ compose one-dimensional chains. The crystal structure can be controlled by adjusting the synthetic methods. Generally, the Pmn $2_{1}$ phase is prepared by hydrothermal method, and $\mathrm{P} 2 / \mathrm{n}$ and Pmnb phase are synthesized via solid state reactions at different tenperatures $\left(600-800^{\circ} \mathrm{C}\right.$ for $\mathrm{P} 2{ }_{1} / \mathrm{n}$ and $\geqslant 900^{\circ} \mathrm{C}$ for Pmnb) [31-34]. Dominko's group [31] demonstrated that the stronger $\mathrm{Fe}-\mathrm{O}$ bonds resulted in a lower $\mathrm{Fe}^{2+} / \mathrm{Fe}^{3+}$ redox potential. The bond lengths of Fe-O in $\mathrm{P} 2_{1} / \mathrm{n}, \mathrm{Pmn} 2_{1}$, and Pmnb phase are $0.2076,0.2032$, and $0.2026 \mathrm{~nm}$, respectively, so Pmnb phase has the lowest redox potential. The Pmnb phase is just obtained at not lower than $900^{\circ} \mathrm{C}$, and thus $\mathrm{P} 2 / \mathrm{n}$ phase is widely studied.

Although LFSO provides the possibility for $\mathrm{Fe}(\mathrm{II})$ to be oxidized to $\mathrm{Fe}(\mathrm{IV})$, there are still many challenges. Firstly, LFSO suffers from inferior electronic conductivity and lithium ion diffusion, which severely hinder its rate performance [35]. Secondly, the existence of site exchange for Fe and $\mathrm{Li}$ at the 1st cycle leads to the decrease of the operation potential [36]. Last, this electrochemical reaction is hard to achieve more than one-electron reaction at room temperature mainly because of the unstable Fe(IV) and the extremely high reaction potential $(4.8 \mathrm{~V})$ [35]. Therefore, intensive efforts are focused on solving the above mentioned difficulties. According to recent published papers, the effective methods include carbon modification, ion-doping, and nanocrystallization $[15,32]$.

Carbon coating/composing is widely applied in materials with poor electronic conductivity and volume expan- 

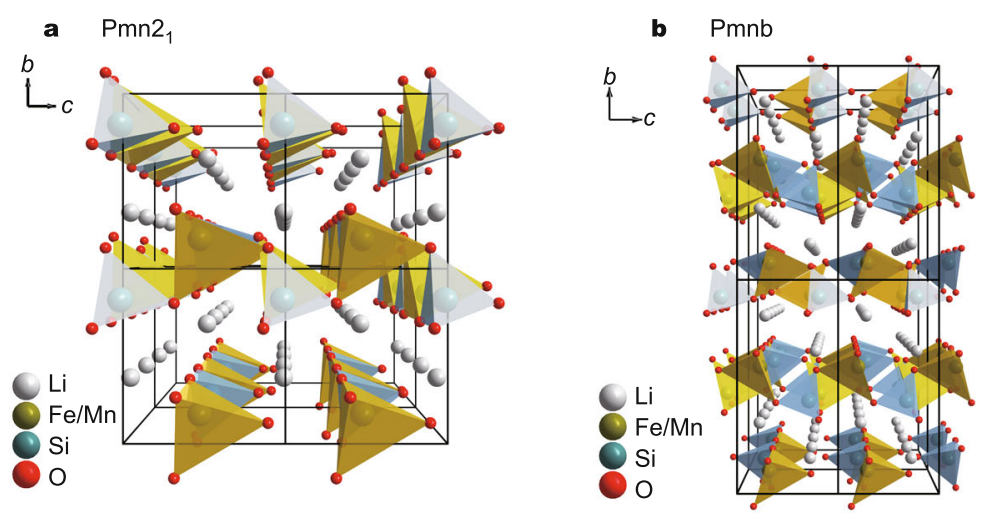

e $R \overline{3}$

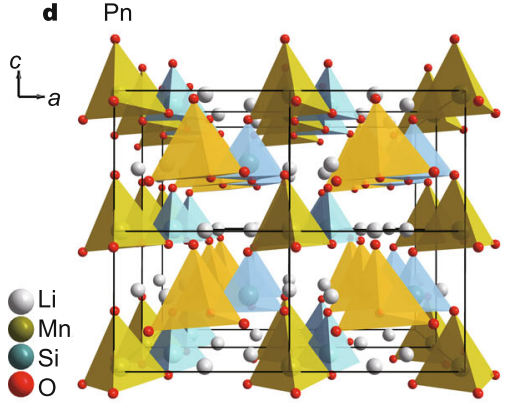

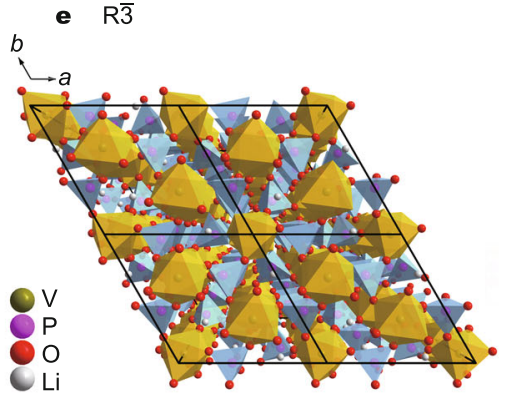
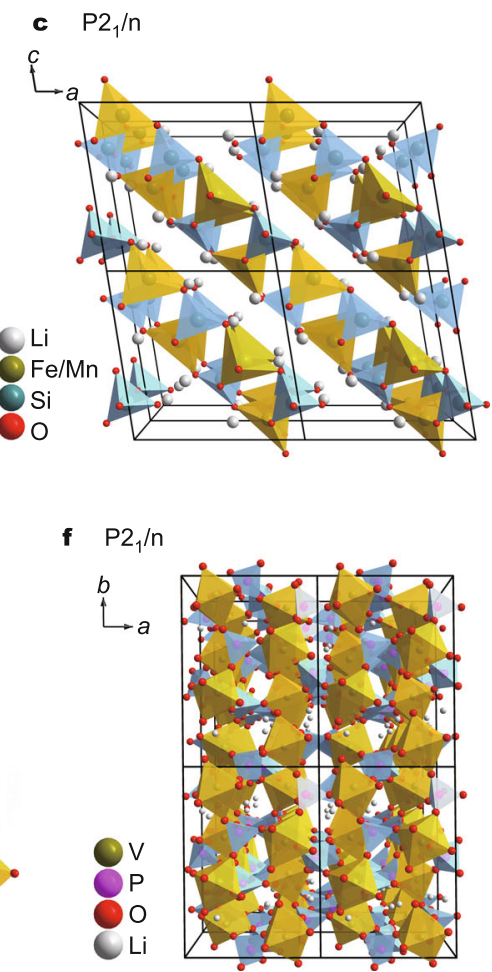

Figure 3 Crystal structures of $\mathrm{Li}_{2} \mathrm{FeSiO}_{4}(\mathrm{a}-\mathrm{c}), \mathrm{Li}_{2} \mathrm{MnSiO}_{4}(\mathrm{a}-\mathrm{d})$, and $\mathrm{Li}_{3} \mathrm{~V}_{2}\left(\mathrm{PO}_{4}\right)_{3}(\mathrm{e}, \mathrm{f})$ polymorphs showing arrangement of FeO $/ \mathrm{MnO}_{4}$ tetrahedra (orange), $\mathrm{SiO}_{4}$ tetrahedra (light blue), $\mathrm{VO}_{6}$ octahedra (orange), and $\mathrm{PO}_{4}$ tetrahedra (light blue) together with $\mathrm{Li}$ ions (white). (a) Orthorhombic Pmn2 phase; (b) orthorhombic Pmnb phase; (c) monoclinic P2 $/ \mathrm{n}$ phase; (d) monoclinic Pn phase; (e) rhombohedral R $\overline{3}$ phase; (f) monoclinic P2 $/ \mathrm{n}$ phase. Unit cells are indicated by black lines.

sion. Exactly for LFSO, carbon coating is the most effective way to enhance its electrochemical performance and to act as the reductant preventing the existence of $\mathrm{Fe}^{3+}$. Our group synthesized spindle-like LFSO through hydrothermal synthesis [33]. Treating with ex-situ carbon coating, LFSO@C nanocomposites with different carbon content were obtained. Among them, the one with $7.21 \mathrm{wt} \%$ carbon showed high discharge capacities of $161 \mathrm{~mA} \mathrm{~h} \mathrm{~g}^{-1}$ at $25^{\circ} \mathrm{C}$ and $213 \mathrm{~mA} \mathrm{~h} \mathrm{~g}^{-1}\left(\sim 1.28 \mathrm{e}^{-}\right)$at $45^{\circ} \mathrm{C}$ at $0.1 \mathrm{C}$. Zhu et al. [34] prepared macroporous graphene/LFSO through solution method by using $\mathrm{Fe}^{3+}$, tetraethyl orthosilicate (TEOS), and $3 \mathrm{D}$ graphene as the main precursors. Because of the $3 \mathrm{D}$ conductive carbon network and the porous structure, the as-prepared sample displayed high capacities of 313 $\mathrm{mA} \mathrm{h} \mathrm{g}^{-1}$ at $0.1 \mathrm{C}$ and $45 \mathrm{~mA} \mathrm{~h} \mathrm{~g}^{-1}$ at $50 \mathrm{C}$.

Nanocrystallization is another way to enhance the properties of LFSO. Although the lithium ion diffusion inside the crystal structure is rather slow, it is possible to reduce the transport time by decreasing the transport length [10]. Meanwhile, this method also provides large specific surface area contributing to more active sites for electrochemical reaction. Our group synthesized porous LFSO@C composite through tartaric-acid assisted sol-gel method. The as-prepared particles had a size of 5-20 nm [32]. The op- timized sample showed the discharge capacities of $\sim 180$ $\mathrm{mA} \mathrm{h} \mathrm{g}^{-1}$ at $0.5 \mathrm{C}$ and $102 \mathrm{~mA} \mathrm{~h} \mathrm{~g}^{-1}$ at $5 \mathrm{C}$. The uniformly dispersed nanoparticles with homogeneous carbon coating are the key factor for the high performance. Xia's group [37] preparedLFSO@C with a particle size of $\sim 30 \mathrm{~nm}$ by a mild solvothermal method followed by thermal vapor deposition (TVD) technology. The obtained powders displayed capacities of $154 \mathrm{~mA} \mathrm{~h} \mathrm{~g}^{-1}$ at $1 \mathrm{C}$ and $121 \mathrm{~mA} \mathrm{~h} \mathrm{~g}^{-1}$ at $5 \mathrm{C}$.

Because the intrinsic electronic conductivity and the lithium ion diffusion are poor, replacing partial $\mathrm{Fe}^{2+}$ or $\mathrm{SiO}_{4}^{4-}$ to bring some defects into the crystal structure would actually enhance the electrochemical performance. Cations like $\mathrm{Al}^{3+}, \mathrm{Co}^{2+}$, and $\mathrm{Mn}^{2+}$ and anions like $\mathrm{PO}_{4}^{3-}$ have proved to offer positive effect on the cell performance [14]. Qian's group [38] synthesized hierarchical mesoporous $\mathrm{Li}_{2} \mathrm{Fe}_{0.5} \mathrm{Mn}_{0.5} \mathrm{SiO}_{4} @ \mathrm{C}$ and procured a high initial discharge capacity of $330 \mathrm{~mA} \mathrm{~h} \mathrm{~g}^{-1}$ and stable cyclic performance expressing as the remained capacity of $125 \mathrm{~mA} \mathrm{~h} \mathrm{~g}^{-1}$ after 60 cycles. Our group [15] synthesized $0.96 \mathrm{Li}_{2} \mathrm{Fe}-$ $\mathrm{SiO}_{4} \cdot 0.04 \mathrm{LiFePO}_{4} @ \mathrm{C}$. The doping materials showed enhanced electrochemical performance of $209 \mathrm{~mA} \mathrm{~h} \mathrm{~g}^{-1}$ at $15^{\circ} \mathrm{C}$ and $284.7 \mathrm{~mA} \mathrm{~h} \mathrm{~g}^{-1}$ at $45^{\circ} \mathrm{C}$ at $0.2 \mathrm{C}$, reduced charge transfer resistance, and improved apparent activation energy. 
$\mathrm{Li}_{2} \mathrm{MnSiO}_{4}$

As another key member in the silicates family, $\mathrm{Li}_{2} \mathrm{MnSiO}_{4}$ (LMSO) also has the capability for achieving two-electron reaction (theoretical capacity of $333 \mathrm{~mA} \mathrm{~h} \mathrm{~g}^{-1}$ ), and possesses the priorities of cheap raw materials and environmental friendliness. The already reported crystal structures of LMSO are Pmn2, Pmnb, P2 /n, and Pn (Figs 3a-d) $[39,40]$. The first three are similar to LFSO, and monoclinic Pn phase was first reported by Abu-Lebdeh's group [40]. In Pn phase, only corner sharing takes place like Pmn2 ${ }_{1}$ phase, and $\mathrm{MnO}_{4}$ and $\mathrm{SiO}_{4}$ tetrahedra have the same pointing direction along the $c$ axis. The relationship of crystal structure and electrochemical performance has been investigated by theoretical calculation. Arroyo-deDompablo's group [41] reported that the calculated average $2 \mathrm{Li}^{+}$intercalation potentials are 4.18, 4.19, and 4.08 V for Pmnb, Pmn2, and $\mathrm{P} 2 / \mathrm{n}$, respectively. Fisher et al. [39] demonstrated that the orthorhombic Pmn2 ${ }_{1}$ phase possesses the lowest $\mathrm{Li}^{+}$migration energy barrier among the four phases.

Similarly to the LFSO, LMSO also suffers from inferior electronic conductivity and lithium ion diffusion. Furthermore, LMSO has bad cyclic performance mainly due to the Jahn-Teller effect [14]. The solving methods are the same as those for LFSO: carbon modification, nanocrystallization, and ion-doping [42-44]. Yang's group [45] synthesized LMSO@C nanocomposite through solution method, and the discharge capacity was $209 \mathrm{~mA} \mathrm{~h} \mathrm{~g}^{-1}$ at the 1 st cycle, which was the first time to accomplish more than one-electron reaction and reversible cyclability among silicates. Our group [16] prepared core-shell structured LMSO@C nanoparticles through hydrothermal assisted solution method. The sample with carbon content of 5.15 wt $\%$ and average particle size of $22.8 \mathrm{~nm}$ showed the enhanced discharge capacities of $282 \mathrm{~mA} \mathrm{~h} \mathrm{~g}^{-1}$ at $0.05 \mathrm{C}$ and $103.4 \mathrm{~mA} \mathrm{~h} \mathrm{~g}^{-1}$ at $5 \mathrm{C}$ (Fig. 4). Zhang et al. [42] prepared Cr-doped LMSO@C nanofibers, and the nanofiber matrix provided fast electron and ion transportation leading to enhanced properties. The $\mathrm{Li}_{2} \mathrm{Mn}_{0.94} \mathrm{Cr}_{0.06} \mathrm{SiO}_{4} @ \mathrm{C}$ sample possessed high discharge capacity of $318 \mathrm{~mA} \mathrm{~h} \mathrm{~g}^{-1}$ at $0.05 \mathrm{C}$.

\section{$\mathrm{Li}_{3} \mathrm{~V}_{2}\left(\mathrm{PO}_{4}\right)_{3}$}

Lithium transition metal phosphate such as $\mathrm{LiFePO}_{4}$ and $\mathrm{LiMnPO}_{4}$ can only reach one-electron reaction, but multielectron can be altered in $\mathrm{Li}_{3} \mathrm{~V}_{2}\left(\mathrm{PO}_{4}\right)_{3}$ (LVP) during cycling. LVP exists in two main classes: rhombohedral $\mathrm{R} \overline{3}$ phase (Fig. 3e) and monoclinic $\mathrm{P} 2 / \mathrm{n}$ phase (Fig. 3f). The rhombohedral LVP possesses a two-electron reaction and displays a charge plateau at $3.8 \mathrm{~V}$ and a discharge plateau at $3.7 \mathrm{~V}$ [46]. However, rhombohedral LVP is not a thermodynamically stable phase, so most reports focus on monoclinic LVP with a high theoretical capacity of $197 \mathrm{~mA} \mathrm{~h} \mathrm{~g}^{-1}$ via a three-electron reaction. The operation voltage ranges
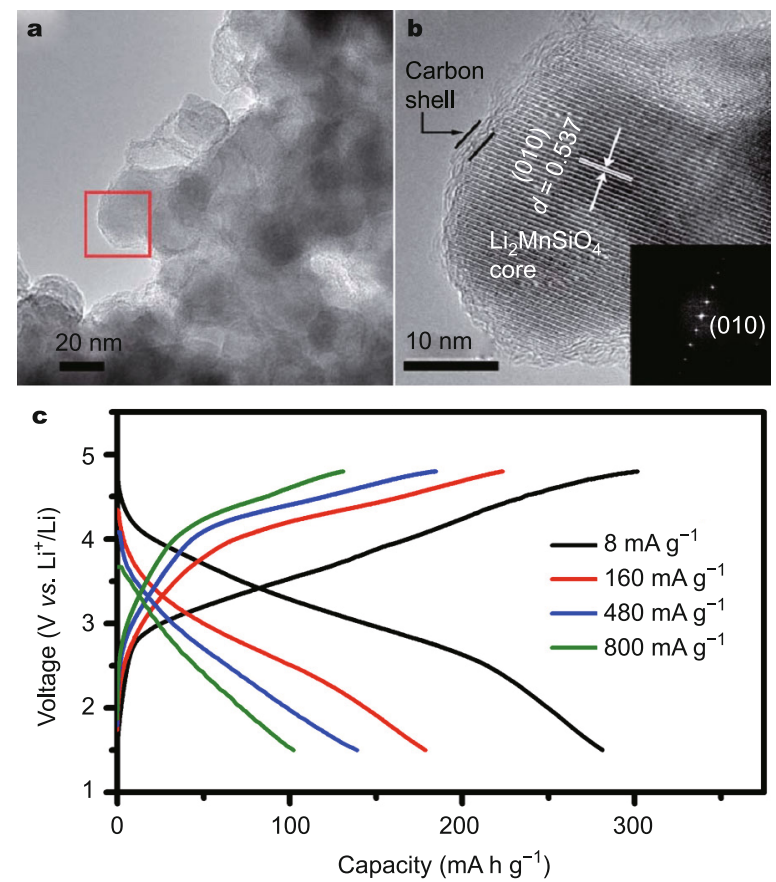

Figure 4 TEM (a) and HRTEM (b) images of LMSO@C nanoparticles. (c) Charge-discharge curves of LMSO@C at different rates. Reprinted with permission from Ref. [16]. Copyright 2013, The Royal Society of Chemistry.

from 3.0 to $4.8 \mathrm{~V}$ together with complex reaction processes. According to previous reports [47-49], during the charge process $\mathrm{Li}_{3} \mathrm{~V}_{2}\left(\mathrm{PO}_{4}\right)_{3}$ turns into $\mathrm{Li}_{2.5} \mathrm{~V}_{2}\left(\mathrm{PO}_{4}\right)_{3}(\sim 3.7 \mathrm{~V})$ and then into $\mathrm{Li}_{2} \mathrm{~V}_{2}\left(\mathrm{PO}_{4}\right)_{3}(\sim 3.8 \mathrm{~V})$ with a process of $\mathrm{V}^{3+}$ to a mixture of $\mathrm{V}^{3+}$ and $\mathrm{V}^{4+}$. Keeping on $\mathrm{Li}^{+}$intercalation, the $\mathrm{Li}_{2} \mathrm{~V}_{2}\left(\mathrm{PO}_{4}\right)_{3}$ transfers into $\mathrm{LiV}_{2}\left(\mathrm{PO}_{4}\right)_{3}(\sim 4.1 \mathrm{~V})$ and then $\mathrm{V}_{2}\left(\mathrm{PO}_{4}\right)_{3}(\sim 4.6 \mathrm{~V})$, with the changes of $\mathrm{V}$ valence from the mixture of $\mathrm{V}^{3+}$ and $\mathrm{V}^{4+}$ into $\mathrm{V}^{4+}$ and then the mixture of $\mathrm{V}^{4+}$ and $\mathrm{V}^{5+}$ signed on the curves. During the discharge process, the fully charged product $\mathrm{V}_{2}\left(\mathrm{PO}_{4}\right)_{3}$ changed to $\mathrm{Li}_{2} \mathrm{~V}_{2}\left(\mathrm{PO}_{4}\right)_{3}$ with a indistinguishable platform from 4.0 to $3.6 \mathrm{~V}$ as solid state behavior. Then, corresponding to the charge state, the platforms at $\sim 3.6$ and $\sim 3.5 \mathrm{~V}$ represent the formation of $\mathrm{Li}_{2.5} \mathrm{~V}_{2}\left(\mathrm{PO}_{4}\right)_{3}$ and $\mathrm{Li}_{3} \mathrm{~V}_{2}\left(\mathrm{PO}_{4}\right)_{3}$. However, a terminal charge potential at $4.8 \mathrm{~V}$ may lead to negative effect on the electrode material expressing as inferior cyclic performance. The modification methods for improving LVP are similar to those of LFSO. Our group [13] synthesized LVP@C nanocomposite through hydrothermal assisted sol-gel method. The uniformly dispersed particles with the size of $33 \mathrm{~nm}$ and homogeneously coated carbon made progress in the improved rate capabilities $\left(\sim 160 \mathrm{~mA} \mathrm{~h} \mathrm{~g}^{-1}\right.$ at $2 \mathrm{C}$ and $120 \mathrm{~mA} \mathrm{~h} \mathrm{~g}^{-1}$ at $20 \mathrm{C}$ ) and long-life cyclability (capacity retention of $86 \%$ after 1,000 cycles).

Other reports focus on the working voltage between 3.0 and $4.3 \mathrm{~V}$, where the cell can display more stable cy- 
clability without the formation of $\mathrm{V}_{2}\left(\mathrm{PO}_{4}\right)_{3}$. Li et al. [50] synthesized ordered macroporous LVP@C nanocomposite by using PMMA as a template. The as-prepared sample showed enhanced discharge capacities of $\sim 156 \mathrm{~mA} \mathrm{~h} \mathrm{~g}^{-1}$ at $0.1 \mathrm{C}$ and $70 \mathrm{~mA} \mathrm{~h} \mathrm{~g}^{-1}$ at $20 \mathrm{C}$. Zhu et al. [51] prepared LVP@rGO (reduced graphene oxide) nanocomposite and the procured performance showed great rate capabilities of $142 \mathrm{~mA} \mathrm{~h} \mathrm{~g}^{-1}$ at $0.075 \mathrm{C}$ and $119 \mathrm{~mA} \mathrm{~h} \mathrm{~g}^{-1}$ at $15 \mathrm{C}$. There was no obvious decrease in the discharge capacity at 0.075 $\mathrm{C}$ after 50 cycles, indicating good cyclic performance.

Overall, the polyanion-type materials are suffering from the sluggish electronic conductivity and lithium ion diffusion as well as the unstable intermediates during cycling. Thus, by treating with carbon modification, nanocrystallization, or cation/anion doping, these kinds of materials would show enhanced electrochemical performance. Although there are still problems to be solved, the high theoretical capacity derived from the multi-electron reaction would have promising applications in LIBs.

\section{Inorganic anode materials}

Most inorganic anode materials have high capacities via multi-electron reaction. According to their reaction mechanism, we can divide them into three categories including alloying reaction (e.g., $\mathrm{Sn}$ and $\mathrm{Si}$ ), conversion reaction (e.g., $\mathrm{Fe}_{2} \mathrm{O}_{3}$ and $\mathrm{MnO}$ ), and intercalation reaction (e.g., $\mathrm{Li}_{4}$ $\left.\mathrm{Ti}_{5} \mathrm{O}_{12}\right)$.

\section{Silicon (Si)}

Si possesses a high theoretical specific capacity of 4,200 $\mathrm{mA} \mathrm{h} \mathrm{g}{ }^{-1}$ based on a 4.4-electron alloying reaction and a low operation voltage of $\sim 0.4 \mathrm{~V} v s$. $\mathrm{Li} / \mathrm{Li}^{+}$[52]. However, huge volume change of $\sim 400 \%$ during the charge/discharge process leads to severe capacity decay and large pulverization. Furthermore, Si is a semiconductor material, and its low conductivity limits the high-rate capability. To solve those issues, two main strategies are used. One is to construct nanostructured or porous $\mathrm{Si}$ to relieve the strain caused by the volume change and shorten the $\mathrm{Li}^{+}$ion diffusion distance $[19,20,53,54]$. Our group [20] prepared nest-like Si nanospheres by solvothermal method, and the Si nanospheres delivered discharge capacities of 3,628 $\mathrm{mA} \mathrm{h} \mathrm{g}^{-1}$ at $0.4 \mathrm{~A} \mathrm{~g}^{-1}$ and $3,052 \mathrm{~mA} \mathrm{~h} \mathrm{~g}^{-1}$ at $2 \mathrm{~A} \mathrm{~g}^{-1}$. Cui's group [19] designed and synthesized double-walled silicon nanotubes with high charge capacities of $2,971 \mathrm{~mA} \mathrm{~h} \mathrm{~g}^{-1}$ at $2 \mathrm{~A} \mathrm{~g}^{-1}$ and $940 \mathrm{~mA} \mathrm{~h} \mathrm{~g}^{-1}$ at $12 \mathrm{C}$ as well as capacity retention of $88 \%$ after 6,000 cycles. Meanwhile, introducing other elements or polymers can buffer the volume change and improve the conductivity [55-57]. Wang and coworkers [57] synthesized $\mathrm{Si} / \mathrm{C}$ fiber paper by electrospraying, and the $\mathrm{Si} / \mathrm{C}$ composite showed a reversible capacity of $\sim 1,200 \mathrm{~mA} \mathrm{~h} \mathrm{~g}^{-1}$ after 100 cycles at $0.5 \mathrm{~A} \mathrm{~g}^{-1}$. Our group $[58,59]$ used mag- netron sputtering to prepare $\mathrm{Si}-\mathrm{Y}$ and sandwich-like $\mathrm{Ti} / \mathrm{Si} /$ Ti thin film anode. The metallic buffer layer suppressed the volume variation of $\mathrm{Si}$ and enhanced the $\mathrm{Li}^{+}$ion diffusion kinetics. Chen and coworkers [56] fabricated polypyrrole (PPY)@porous hollow Si spheres which showed the outstanding cycling stability with capacity retention of $88 \%$ after 250 cycles at $1 \mathrm{~A} \mathrm{~g}^{-1}$ compared with the second capacity.

\section{$\operatorname{Tin}(\mathrm{Sn})$}

Sn has also attracted intensive interest owing to its high theoretical specific capacity of $990 \mathrm{~mA} \mathrm{~h} \mathrm{~g}^{-1}$ based on a 4.4-electron alloying reaction. Nevertheless, $\mathrm{Sn}$ is also plagued by large volume change. To maintain the structural stability, many Sn-based composites have been attempted [18,60-65]. Our group prepared ultrasmall Sn nanoparticles with a particle size of $\sim 5 \mathrm{~nm}$ homogenously embedded in $\mathrm{N}$-doped porous carbon $(5-\mathrm{Sn} / \mathrm{C})$ by carbonizing the Sn (Salen) (Fig. 5) [18]. The Sn/C composite showed an initial discharge capacity of $1,014 \mathrm{~mA} \mathrm{~h} \mathrm{~g}^{-1}$ with capacity retention of $71.2 \%$ after 200 cycles at $0.2 \mathrm{~A} \mathrm{~g}^{-1}$. Even at a high current density of $5 \mathrm{~A} \mathrm{~g}^{-1}$, a reversible capacity of $\sim 480 \mathrm{~mA} \mathrm{~h} \mathrm{~g}^{-1}$ was obtained. Our group also reported the synthesis of the pitaya-like Sn@C nanocomposite via an aerosol spray pyrolysis route [65]. In the composite, Sn nanoparticles with a particle size of $\sim 8 \mathrm{~nm}$ are uniformly dispersed in the carbon spheres. The composite delivered a capacity of $410 \mathrm{~mA} \mathrm{~h} \mathrm{~g}^{-1}$ after 1,000 cycles at $4,000 \mathrm{~mA} \mathrm{~g}^{-1}$

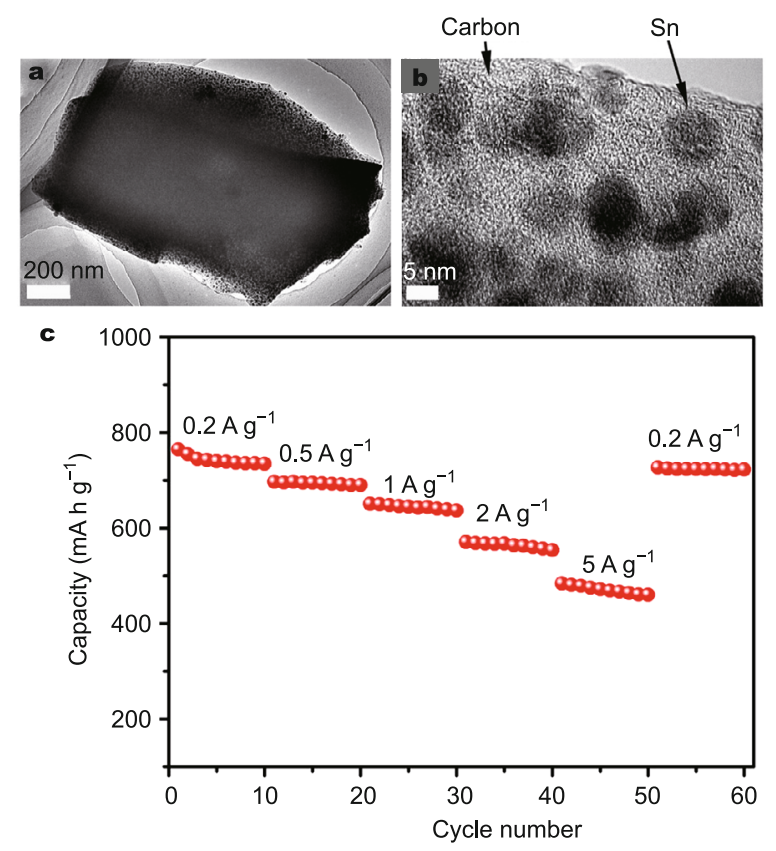

Figure 5 (a) TEM image, (b) HRTEM image, and (c) rate capability of ultrasmall $\mathrm{Sn}$ nanoparticles dispersed in $\mathrm{N}$-doped porous carbon matrix (5-Sn/C). Reprinted with permission from Ref. [18]. Copyright 2013, American Chemical Society. 
(6.1 C). Cho's group [63] synthesized core-shell Sn-Cu nanoalloys with a particle size of $10 \mathrm{~nm}$, and the $\mathrm{Sn}-\mathrm{Cu}$ composite displayed a charge capacity of $620 \mathrm{~mA} \mathrm{~h} \mathrm{~g}^{-1}$ at $6 \mathrm{C}$.

\section{Phosphorus (P)}

$\mathrm{P}$ is another promising anode material with a theoretical specific capacity of $2,595 \mathrm{~mA} \mathrm{~h} \mathrm{~g}^{-1}$ based on the reaction of $3 \mathrm{Li}+\mathrm{P} \leftrightarrow \mathrm{Li}_{3} \mathrm{P}$. However, $\mathrm{P}$ suffers from dramatic capacity fade after a few cycles because of its large volume expansion and poor conductivity. So far, there are only a few reports about $\mathrm{P}$, in which $\mathrm{P}-\mathrm{C}$ composites have been used to overcome the problems $[21,66,67]$. He's group [21] prepared $\mathrm{P}-\mathrm{C}$ composite by heating the mixture of red $\mathrm{P}$ and porous carbon at $450^{\circ} \mathrm{C}$ in a seal vessel. The composite exhibited an initial capacity of $2,413 \mathrm{~mA} \mathrm{~h} \mathrm{~g}^{-1}$ with capacity retention of $87 \%$ from the 2 nd to 55 th cycle at $100 \mathrm{~mA} \mathrm{~g}^{-1}$, but the $\mathrm{P}$ content is only $30.56 \mathrm{wt} \%$. Sohn and co-authors [67] reported a carbon/black P composite with an initial discharge capacity of $2,010 \mathrm{~mA} \mathrm{~h} \mathrm{~g}^{-1}$. Nevertheless, black $\mathrm{P}$ is a thermodynamically unstable phase, which is very difficult to synthesize. $\mathrm{P}$ anode still faces the problems how to increase the content of $\mathrm{P}$ and improve the electrochemical performance.

\section{Metal oxides}

Metal oxides can react with $\mathrm{Li}^{+}$through a conversion reaction as follows [68]:

$$
\begin{gathered}
\mathrm{M}_{x} \mathrm{O}_{y}+2 y \mathrm{Li}^{+}+2 y \mathrm{e}^{-} \leftrightarrow x \mathrm{M}+y \mathrm{Li}_{2} \mathrm{O} \\
(\mathrm{M}: \mathrm{Fe}, \mathrm{Co}, \mathrm{Ni}, \mathrm{Mn} \text {, etc.). }
\end{gathered}
$$

Though metal oxides possess high theoretical specific capacity, they suffer from severe structural change resulted from conversion reactions, which makes it difficult for them to achieve long-term cyclability. Designing the nanostructure/porous structure and preparing $\mathrm{M}_{x} \mathrm{O}_{y} / \mathrm{C}$ composite are effective means to keep the structural stability. Our group used templating method to synthesize $\alpha-\mathrm{Fe}_{2} \mathrm{O}_{3}$ and $\mathrm{Co}_{3} \mathrm{O}_{4}$ nanotubes with high initial capacities, but the cycling performance was not ideal $[22,69]$. Cho's group [23] produced spindle-like porous $\alpha-\mathrm{Fe}_{2} \mathrm{O}_{3}$ by using metal organic framework (MOF) as a template. The porous $\alpha-\mathrm{Fe}_{2} \mathrm{O}_{3}$ showed a reversible capacity of $911 \mathrm{~mA} \mathrm{~h} \mathrm{~g}^{-1}$ after 50 cycles at $0.2 \mathrm{C}$. Even at a high rate of $10 \mathrm{C}$, the discharge capacity still reached $424 \mathrm{~mA} \mathrm{~h} \mathrm{~g}^{-1}$. Sun et al. [70] fabricated $\mathrm{MnO} /$ graphene composite which presented reversible capacities of $2,014.1 \mathrm{~mA} \mathrm{~h} \mathrm{~g}^{-1}$ at $0.2 \mathrm{~A} \mathrm{~g}^{-1}$ and $843.3 \mathrm{~mA} \mathrm{~h} \mathrm{~g}^{-1}$ at 2 $\mathrm{A} \mathrm{g}^{-1}$. The specific capacity exceeded the theoretical value, because $\mathrm{Mn}$ (II) was further oxidized to $\mathrm{Mn}$ (IV) which contributed to supernumerary capacity. Although many efforts have been made to improve the performance of the metal oxides with conversion reactions, their commercialization is still difficult to achieve because of their relatively high operation potential and severe structural damage.

$\mathrm{Li}_{4} \mathrm{Ti}_{5} \mathrm{O}_{12}$

Spinel $\mathrm{Li}_{4} \mathrm{Ti}_{5} \mathrm{O}_{12}$ (LTO) can react with $3 \mathrm{Li}^{+}$to form $\mathrm{Li}_{7}$ $\mathrm{Ti}_{5} \mathrm{O}_{12}$, and its potential plateau is $\sim 1.55 \mathrm{~V}$ which avoids the formation of lithium dendrites. In addition, the structure of LTO does not change during the charge/discharge process, leading to outstanding cyclability. However, the intrinsically low electrical conductivity and Li ion diffusion coefficient of LTO limit its rate performance. To overcome these issues, two methods are proposed. One is to reduce the particle size or design the nanoporous structure [71-73]. Feckl et al. [72] prepared highly porous LTO with a surface area of $205 \mathrm{~m}^{2} \mathrm{~g}^{-1}$ and a uniform pore size of 7 $\mathrm{nm}$ by hydrothermal method combined with heating treatment. The porous LTO delivered ultrahigh-rate capabilities $\left(173 \mathrm{~mA} \mathrm{~h} \mathrm{~g}^{-1}\right.$ at $100 \mathrm{C}$ and $128 \mathrm{~mA} \mathrm{~h} \mathrm{~g}^{-1}$ at $\left.800 \mathrm{C}\right)$. Lou's group [73] reported a simple templating method for the synthesis of mesoporous LTO hollow spheres, exhibiting a reversible capacity of $\sim 120 \mathrm{~mA} \mathrm{~h} \mathrm{~g}^{-1}$ after 300 cycles at 5 C. The other is surface coating with carbon materials or oxides [24,74-76]. Our group investigated the effect of the coated carbon of LTO on its electrochemical performance by in situ Raman spectroscopy [24]. Through balancing the electronic conduction and the ionic transport, the carbon content could be optimized. Guo's and Wan's group [75] reported rutile- $\mathrm{TiO}_{2}$ coated LTO nanosheets with a discharge capacity of $149 \mathrm{~mA} \mathrm{~h} \mathrm{~g}^{-1}$ after 100 cycles at $20 \mathrm{C}$. The $\mathrm{TiO}_{2}$ layer enhanced the surface stability and cycle life. Although LTO only has a theoretical specific capacity of $175 \mathrm{~mA} \mathrm{~h} \mathrm{~g}^{-1}$, it has exhibited high-rate capability and long life, so it can be applied for the EESC devices with high specific power.

Although anode materials have large specific capacity except for LTO, they usually suffer from large volume change during $\mathrm{Li}^{+}$intercalation and deintercalation. Nanostructured $\mathrm{Sn} / \mathrm{C}$ and $\mathrm{Si} / \mathrm{C}$ composites deliver improved cycling and rate performance, which offers a great promise for next-generation LIBs.

\section{Organic carbonyl compounds}

Organic electrode materials, especially organic carbonyl compounds, possess high capacity because of their high transfer electron number and low molecular weight. The electrochemical redox reactions of organic carbonyl compounds are two- or multi-electron transfer processes. For example, benzoquinone (BQ) first gains one electron to generate radical anion $\left(\mathrm{BQ}^{-}\right)$, and then gains another electron to form $\mathrm{BQ}^{2-}$ (Fig. 6).

Up to now, there have been some interesting results for organic electrode materials. Fig. 7 shows the molecular structure and theoretical specific capacity of the repre- 


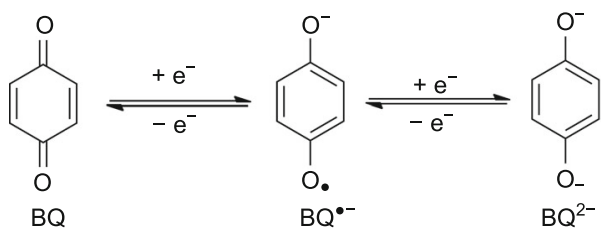

Figure 6 Electrochemical redox reaction mechanism of benzoquinone (BQ).<smiles>O=C1C=CC(=O)C=C1</smiles>

$\mathrm{BQ}$<smiles>O=C1c2ccccc2C(=O)c2ccccc21</smiles>

$A Q$<smiles>O=C1c2ccncc2C(=O)c2ccncc21</smiles>

PID<smiles>O=C1c2ccsc2C(=O)c2sccc21</smiles>

BDTD<smiles>O=C1c2ccoc2C(=O)c2ccoc21</smiles>

BFFD

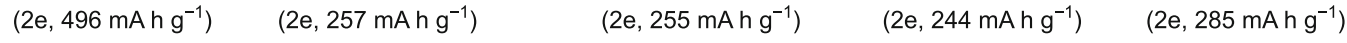

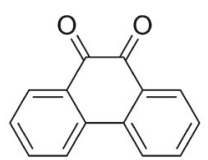

$P Q$

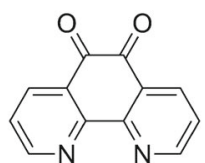

PhenQ<smiles>O=C1C(=O)c2sccc2-c2ccsc21</smiles>

BDTQ

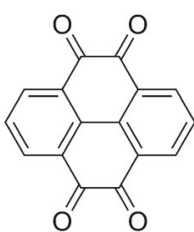

PTO $\left(2 \mathrm{e}, 255 \mathrm{~mA} \mathrm{~h} \mathrm{~g}^{-1}\right) \quad\left(2 \mathrm{e}, 244 \mathrm{~mA} \mathrm{~h}^{-1}\right) \quad\left(4 \mathrm{e}, 409 \mathrm{~mA} \mathrm{~h} \mathrm{~g}^{-1}\right)$<smiles>O=C1C(=O)N(c2ccccc2)C(=O)C(=O)N1c1ccccc1</smiles>

PHP<smiles>O=C1OC(=O)c2ccc3c4c(ccc1c24)C(=O)OC3=O</smiles>

NTCDA<smiles>CN1C(=O)c2ccc3c4c(ccc(c24)C1=O)C(=O)N(C)C3=O</smiles>

$\left(2 \mathrm{e}, 182 \mathrm{~mA} \mathrm{~h} \mathrm{~g}^{-1}\right)$<smiles></smiles>

$\left(4 \mathrm{e}, 446 \mathrm{~mA} \mathrm{~h} \mathrm{~g}^{-1}\right)$<smiles>O=C1C=C(O)C(=O)C=C1O</smiles>

$$
\mathrm{Li}_{2} \mathrm{C}_{6} \mathrm{H}_{2} \mathrm{O}_{4}
$$

(2e, $353 \mathrm{~mA} \mathrm{~h} \mathrm{~g}^{-1}$ )<smiles>O=c1c(O)c(O)c(=O)c(=O)c1=O</smiles>

$\mathrm{Li}_{2} \mathrm{C}_{6} \mathrm{O}_{6}$

$\left(4 \mathrm{e}, 589 \mathrm{~mA} \mathrm{~h} \mathrm{~g}^{-1}\right)$<smiles>O=C1C=C(C2=CC(=O)c3ccccc3C2=O)C(=O)c2ccccc21</smiles>

$\mathrm{BNQ}$ $\left(4 \mathrm{e}, 341 \mathrm{~mA} \mathrm{~h} \mathrm{~g}^{-1}\right)$<smiles>O=C1C(O)=C(C2=C(O)C(=O)c3ccccc3C2=O)C(=O)c2ccccc21</smiles>

$\mathrm{H}_{2} \mathrm{HNQ}$

$\left(4 \mathrm{e}, 310 \mathrm{~mA} \mathrm{~h} \mathrm{~g}^{-1}\right)$

Figure 7 Molecular structure and theoretical specific capacity of the representative organic carbonyl compounds.<smiles>O=C1C(=O)C(O)C(=O)C(Cl)=C1Cl</smiles>

$\mathrm{Li}_{4} \mathrm{C}_{6} \mathrm{O}_{6}$

$\left(2 \mathrm{e}, 274 \mathrm{~mA} \mathrm{~h} \mathrm{~g}^{-1}\right)$<smiles>O=C(OCl)c1ccc(C(=O)OCl)cc1</smiles>

$\mathrm{Li}_{2} \mathrm{C}_{8} \mathrm{H}_{4} \mathrm{O}_{4}$

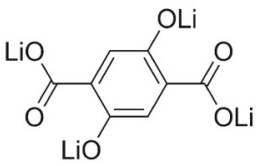

$\mathrm{Li}_{4} \mathrm{DHTPA}$

(2e, $242 \mathrm{~mA} \mathrm{~h} \mathrm{~g}^{-1}$ ) 
sentative organic carbonyl compounds. Although organic carbonyl compounds are greatly various, they receive less concern than inorganic electrode materials for a long time, because of their intrinsically low electrical conductivity and easy dissolution in organic electrolytes like Li-S batteries. Recently, much progress has been made, such as molecular-level engineering design, increasing the molecular weight by polymerization, enhancing the polarity by using organic lithium salts, and enveloping the active materials in a conductive container [77,78].

\section{Molecular engineering design}

Though organic compounds are easy to design and processing, there are only a few reports on the molecular-level engineering design of organic electrode materials. Our group used the density functional theory (DFT) calculations to predict the average discharge voltage and the active site availability of organic carbonyl compounds [26,79]. The linear relationship between the discharge potential and the calculated lowest unoccupied molecular orbital (LUMO) energy of fused heteroaromatic organic compounds was first proposed. Low LUMO energy is favorable to improve the discharge potential. According to our calculated results, a series of fused heteroaromatic organic compounds were designed and prepared, including furan (benzofuro[5,6-b]furan-4,8-dione, BFFD), thiophene (benzo[1,2-b: 4,5-b']dithiophene-4,8-dione, BDTD), and pyridine (pyrido[3,4-g] isoquinoline-5,10-dione, PID) [79]. These compounds as cathode materials of LIBs presented higher operation potential, cyclability, and rate performance than those of benzene-fused analogue (anthraquinone, AQ). Especially, BFFD showed a discharge capacity of $181 \mathrm{~mA} \mathrm{~h} \mathrm{~g}^{-1}$ at a high rate of $100 \mathrm{C}$. We also first proposed to use the highest occupied molecular orbital plots and thermodynamic energy change of organic carbonyl compounds to predict carbonyl utilization, which explained that for organic compounds with four carbonyl groups, why four-electron reaction could occur in pyrene-4,5,9,10-tetraone (PTO) and dilithium rhodizonate salt $\left(\mathrm{Li}_{2} \mathrm{C}_{2} \mathrm{O}_{6}\right)$, while only two-electron reaction could occur in N,N'-diphenyl-2,3,5,6-tetraketopiperazine (PHP) and 1,4,5,8-naphthalenetetracarboxylic dianhydride (NTCDA) [26].

\section{Restriction of dissolution}

Increasing the molecular weight by polymerization and enhancing the polarity by using organic lithium salts both can reduce the dissolution of organic electrode materials, leading to improved cycling performance. Nokami et al. [80] prepared polymer-bound PTO (PPYT) which delivered an initial discharge capacity of $231 \mathrm{~mA} \mathrm{~h} \mathrm{~g}^{-1}$ and capacity retention of $83 \%$ after 500 cycles at $1 \mathrm{C}$. Tarascon's group $[81,82]$ synthesized lithium salts of tetrahydroxybenzo- quinone and terephthalic acid $\left(\mathrm{Li}_{2} \mathrm{C}_{2} \mathrm{O}_{6}\right.$ and $\left.\mathrm{Li}_{2} \mathrm{C}_{8} \mathrm{H}_{4} \mathrm{O}_{4}\right)$. $\mathrm{Li}_{2} \mathrm{C}_{6} \mathrm{O}_{6}$ showed a reversible capacity of $\sim 200 \mathrm{~mA} \mathrm{~h} \mathrm{~g}^{-1}$ at $2.7 \mathrm{~V}$ via a two-electron reaction to form $\mathrm{Li}_{2} \mathrm{C}_{6} \mathrm{O}_{6}$, and lithium-salted $\mathrm{Li}_{2} \mathrm{C}_{8} \mathrm{H}_{4} \mathrm{O}_{4}$ exhibited a stable capacity of 234 $\mathrm{mA} \mathrm{h} \mathrm{g}^{-1}$ after 50 cycles with a potential plateau of $0.8 \mathrm{~V}$. Combining the two molecules, our group developed tetralithium salts of 2,5-dihydroxyterephthalic acid $\left(\mathrm{Li}_{4} \mathrm{C}_{8} \mathrm{H}_{2} \mathrm{O}_{6}\right)$ nanosheets as both cathode and anode materials [25]. For cathode, a two-electron reaction could occur with the redox couple $\mathrm{Li}_{4} \mathrm{C}_{8} \mathrm{H}_{2} \mathrm{O}_{6} / \mathrm{Li}_{2} \mathrm{C}_{8} \mathrm{H}_{2} \mathrm{O}_{6}$ at $\sim 2.6 \mathrm{~V}$, and for anode, a two-electron reaction could occur with the redox couple $\mathrm{Li}_{4} \mathrm{C}_{8} \mathrm{H}_{2} \mathrm{O}_{6} / \mathrm{Li}_{6} \mathrm{C}_{8} \mathrm{H}_{2} \mathrm{O}_{6}$ at $\sim 0.8 \mathrm{~V}$. The all-organic LIBs delivered a reversible capacity of $225 \mathrm{~mA} \mathrm{~h} \mathrm{~g}^{-1}$ with an average operation voltage of $\sim 1.8 \mathrm{~V}$.

Besides optimizing the organic molecules, the quasi-solid-state electrolytes can also improve the cycling performance. Our group demonstrated that a poly(methacrylate) (PMA)/poly(ethylene glycol) (PEG) based gel polymer electrolyte (GPE) could be used as the electrolyte of organic LIBs with high capacity $[27,83]$. The PMA/PEG-based GPE combined with calix[4] quinone (C4Q) and pillar[5] quinone $(\mathrm{P} 5 \mathrm{Q})$ to form two quasi-solid-state LIBs. The quasi-solid-state LIBs with C4Q delivered an initial discharge capacity of $422 \mathrm{~mA} \mathrm{~h} \mathrm{~g}^{-1}$ at $0.2 \mathrm{C}$ and a reversible capacity of $379 \mathrm{~mA} \mathrm{~h} \mathrm{~g}^{-1}$ after 100 cycles [27], and P5Q displayed an initial capacity of $410 \mathrm{~mA} \mathrm{~h} \mathrm{~g}^{-1}$ with capacity retention of $88.5 \%$ after 100 cycles [83].

\section{Improvement of conductivity}

Carbon materials have high electronic conductivity, which is favorable to improve the $\mathrm{Li}^{+}$diffusion kinetics of organic carbonyl compounds, leading to high rate performance. Moreover, some porous carbon materials can confine the organic small molecule to reduce its dissolution in organic electrolytes. Our group developed a facile ultrasonic method to prepare 2,2'-bis(3-hydroxy-1,4-naphthoquinone) ( $\mathrm{H}_{2} \mathrm{BHNQ}$ )/mesoporous CMK-3 carbon composite with 50 wt $\% \mathrm{H}_{2} \mathrm{BHNQ}$ [84]. The composite showed discharge capacities of $308.6 \mathrm{~mA} \mathrm{~h} \mathrm{~g}^{-1}$ at $0.1 \mathrm{C}$ and $124.0 \mathrm{~mA} \mathrm{~h} \mathrm{~g}^{-1}$ at $10 \mathrm{C}$. Song et al. [85] synthesized poly(anthraquinonyl sulfide) (PAQS)-graphene nanocomposite which showed a discharge capacity of $100 \mathrm{~mA} \mathrm{~h} \mathrm{~g}^{-1}$ at a high rate of $100 \mathrm{C}$.

Although organic carbonyl compounds have developed rapidly in the past few years, their operation potential is difficult to exceed 3.0 V. Exploiting the organic carbonyl compounds with high operation potential and practical capacity is urgent and necessary in the future.

\section{Li-S BATTERIES}

Li-S batteries with a two-electron reaction possess a high specific capacity of $1,675 \mathrm{~mA} \mathrm{~h} \mathrm{~g}^{-1}$ and a high specific energy of $2,600 \mathrm{~W} \mathrm{~h} \mathrm{~kg}^{-1}$. The sulfur cathode usually discharges 
with two plateaus at $\sim 2.3 \mathrm{~V}$ and $\sim 1.95 \mathrm{~V}$, corresponding to the redox couples of $\mathrm{S}_{8} / \mathrm{Li}_{2} \mathrm{~S}_{x}(x=4-8)$ and $\mathrm{Li}_{2} \mathrm{~S}_{x}(x=4-8)$ / $\mathrm{Li}_{2} \mathrm{~S}$, respectively. Although the concept of Li-S batteries was proposed in the 1940s, they have developed rapidly only after 2009 [86]. Two main factors limit the electrochemical performance of Li-S batteries [9]. One is low conductivity and large volume change of sulfur, leading to sluggish kinetics and poor cyclability. The other is that the intermediate long-chain lithium polysulfides are very soluble in organic electrolytes, which causes the "shuttle loss". Because carbonate-based electrolytes react with polysulfides [87], we have to use expensive ether-based electrolytes, leading to high cost of Li-S batteries. Of course, safety issue derived from Li dendrite is a problem of all Li metal batteries. To solve these problems, many strategies have been proposed, including preparing the carbon-sulfur composite, optimizing the organic electrolytes, and using the short-chain $\mathrm{S}_{2-4}$ and $\mathrm{Li}_{2} \mathrm{~S}$ alternative to $\mathrm{S}_{8}[88,89]$.

\section{Carbon-sulfur composite and conducting polymer coating}

Encapsulating sulfur in carbon materials and/or conducting polymers is a most commonly used means to improve the conductivity and constrain the "shuttle loss". Nazar's group [86] prepared polyethylene glycol (PEG)-coated CMK-3/S composite, and the composite delivered a capacity of 1,320 $\mathrm{mA} \mathrm{h} \mathrm{g} \mathrm{g}^{-1}$ at $0.1 \mathrm{C}$. CMK-3 as conductive mesoporous carbon framework accommodates the volume change during the charge-discharge process, improves the adsorption capability, and enhances the $\mathrm{Li}^{+}$diffusion kinetics. Polymer modification further inhibits the dissolution of lithium ploysulfides and provides a chemical diffusion gradient.

Besides mesoporous carbon, other carbon materials such as graphene, carbon nanotubes, carbon fibers, and porous carbon spheres are also attempted [90-93]. Our group [12] reported a composite of sulfur impregnated in porous hollow carbon spheres (PHCS) with high discharge capacities of $1,450 \mathrm{~mA} \mathrm{~h} \mathrm{~g}^{-1}$ at $0.05 \mathrm{C}$ and $1,068 \mathrm{~mA} \mathrm{~h} \mathrm{~g}^{-1}$ at 0.5 $\mathrm{C}$ (Fig. 8). The high performance is attributed to the high electronic conductivity and hierarchical porous structure of PHCS. Wang's group [93] synthesized 3D hyperbranched hollow carbon nanorods (CNR) as a sulfur container, and the CNR/S nanocomposite displayed specific capacities of $1,378 \mathrm{~mA} \mathrm{~h} \mathrm{~g}^{-1}$ at $0.1 \mathrm{C}$ and $663 \mathrm{~mA} \mathrm{~h} \mathrm{~g}^{-1}$ at $10 \mathrm{C}$.

Conducting polymers such as poly(3,4-ethylenedioxythio phene) (PEDOT), polypyrrole (PPY), polyaniline (PANI), and polyacrylonitrile (PAN) have been explored to envelop the sulfur [94-98]. The polymer coating can not only physically confine the dissolution of lithium polysulfides, but also chemically bond with lithium polysulfides. Cui's group [96] prepared three polymer/hollow sulfur nanosphere composites, and their performance decreased in the order of PEDOT > PPY > PANI because of their dif-
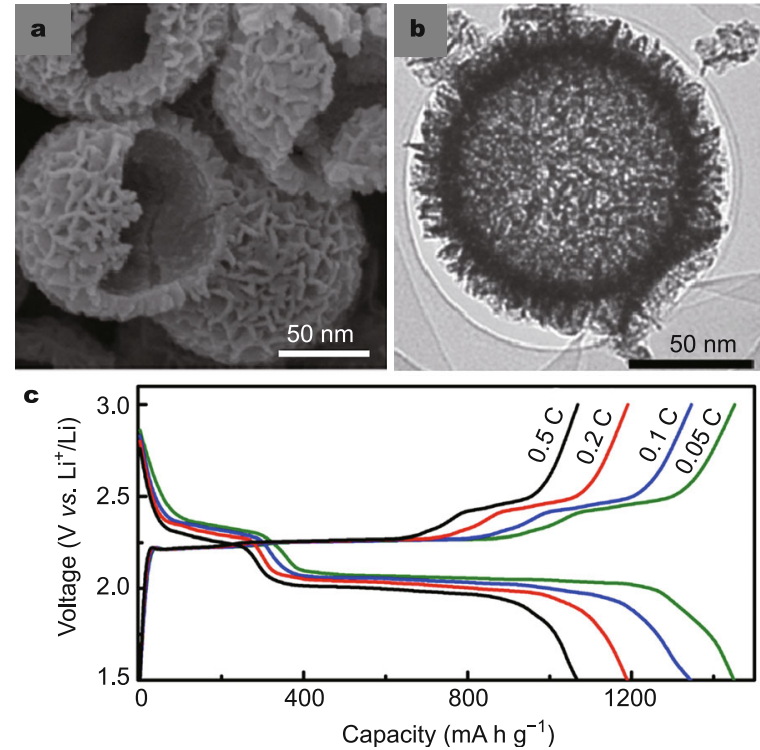

Figure 8 SEM (a) and TEM (b) images of porous hollow carbon sphere (PHCS)/S nanocomposite. (c) Charge and discharge curves of PHCS/S nanocomposite at different rates. Reprinted with permission from Ref. [12]. Copyright 2013, Tsinghua University Press and Springer-Verlag.

ferent conductivities. It was found that S-PAN composite showed a reversible capacity of $\sim 800 \mathrm{~mA} \mathrm{~h}^{-1}$ and high capacity retention of more than $98.1 \%$ after 50 cycles at 100 $\mathrm{mA} \mathrm{g}^{-1}$ [97].

\section{Small sulfur molecules}

In most reports, stable cyclooctasulfur $\left(\right.$ cyclo- $\left._{8}\right)$ is used as the cathode of Li-S batteries. Involuntarily, when melt sulfur is impregnated into the microporous carbon, metastable small sulfur molecules $\left(\mathrm{S}_{2-4}\right)$ are found [99]. The small sulfur molecules discharge with only one plateau at $\sim 1.9 \mathrm{~V}$, which avoids the formation of long-chain lithium polysulfides and essentially solves the "shuttle loss". Furthermore, carbonate-based electrolytes can be used in this Li-S battery system, which substantially lower the cost. Guo's and Wan's group [99] first reported small sulfur molecules embedded in a microporous carbon with a pore size of $\sim 0.5 \mathrm{~nm}$, and the composite showed an initial capacity of $1,670 \mathrm{~mA} \mathrm{~h} \mathrm{~g}^{-1}$ at $0.1 \mathrm{C}$ and a reversible capacity of $1,142 \mathrm{~mA} \mathrm{~h} \mathrm{~g}^{-1}$ after 200 cycles. However, it is difficult to achieve high sulfur content for the microporous carbon, so combining the advantages of mesoporous carbon and microporous carbon is necessary. Li et al. [100] prepared ordered meso-microporous core-shell carbon (MMCS)/S composite which exhibited a capacity of $837 \mathrm{~mA} \mathrm{~h} \mathrm{~g}^{-1}$ at $0.5 \mathrm{C}$ after 200 cycles. The mesoporous carbon "core" possesses large pore volume to improve the load amount of sulfur, and the microporous carbon "shell" has a strong adsorbing ability to inhibit the dissolution of polysulfides. 


\section{$\mathrm{Li}_{2} \mathrm{~S}$ cathode}

To solve the safety hazard of Li dendrite, Cui's group [101] proposed to use $\mathrm{Li}_{2} \mathrm{~S}$ cathode coupled with lithium-free high-capacity anodes (e.g., $\mathrm{Si}$ and $\mathrm{Sn}$ ) to compose a novel Li-ion battery. $\mathrm{Li}_{2} \mathrm{~S}$ has a theoretical specific capacity of $1,166 \mathrm{~mA} \mathrm{~h} \mathrm{~g}^{-1}$, and the breakage of its volume contraction is less than volume expansion of sulfur electrode during the first charge process. However, $\mathrm{Li}_{2} \mathrm{~S}$ also suffers from low electronic conductivity and "shuttle loss". The efforts used in the sulfur cathode are attempted to solve the problems of $\mathrm{Li}_{2} \mathrm{~S}$ cathode. Manthiram's group [102] fabricated a sandwiched electrode with bulky $\mathrm{Li}_{2} \mathrm{~S}$ powder in the middle and self-weaving carbon nanotubes on both sides. At $0.1 \mathrm{C}$, a discharge capacity of $838 \mathrm{~mA} \mathrm{~h} \mathrm{~g}^{-1}$ was obtained. Cui's group [103] prepared PPY/ $\mathrm{Li}_{2} \mathrm{~S}$ composites via in-situ polymerization method. The $\mathrm{N}$ atoms of PPY could form $\mathrm{Li}-\mathrm{N}$ bond with $\mathrm{Li}_{2} \mathrm{~S}$, which confined the dissolution of polysulfides. The PPY/Li 2 composites exhibited a discharge capacity of $785 \mathrm{~mA} \mathrm{~h} \mathrm{~g}^{-1}$ with excellent cycling stability at $0.2 \mathrm{C}$. Li's group [104] synthesized the core-shell structured $\mathrm{Li}_{2} \mathrm{~S} @ \mathrm{C}$ spheres with particle size of $1 \mu \mathrm{m}$ via a chemical vapor deposition (CVD) method. The $\mathrm{Li}_{2} \mathrm{~S} @ \mathrm{C}$ spheres showed stable cycling performance, and when the $\mathrm{Li}_{2} \mathrm{~S}$ content reached $88 \mathrm{wt} \%$ in the electrode, the morphology of the electrode still changed little after 400 cycles at $0.5 \mathrm{C}$.

In addition, $\mathrm{Li}_{2} \mathrm{~S}$ is plagued by the large potential barrier during the first charge process, leading to a utilized capacity penalty. Although setting a high charging cutoff voltage (more than $4 \mathrm{~V}$ ) can compulsively activate $\mathrm{Li}_{2} \mathrm{~S}$, it results in unnecessary energy loss. Downsizing $\mathrm{Li}_{2} \mathrm{~S}$ particles combined with a highly conductive matrix can boost the electrode kinetics, which benefits the activation of $\mathrm{Li}_{2} \mathrm{~S}$ [105]. Our group [17] prepared ultrafine $\mathrm{Li}_{2} \mathrm{~S}$ nanoparticles $(\sim 8.5 \mathrm{~nm})$ uniformly dispersed in graphene nanosheets. The graphene/ $\mathrm{Li}_{2} \mathrm{~S}$ nanocomposite presented an initial discharge capacity of $1,119 \mathrm{~mA} \mathrm{~h} \mathrm{~g}^{-1}$ and almost invisible potential barrier in the first cycle at $0.02 \mathrm{C}$. At a high rate of $2 \mathrm{C}$, the discharge capacity still reached $565 \mathrm{~mA} \mathrm{~h} \mathrm{~g}^{-1}$. The graphene $/ \mathrm{Li}_{2} \mathrm{~S}$ nanocomposite also combined with the $\mathrm{Si}$ thin film anode to form a full cell, and the full cell exhibited a high discharge capacity of $900 \mathrm{~mA} \mathrm{~h} \mathrm{~g}^{-1}$ at $0.05 \mathrm{C}$. The $\mathrm{Li}_{2} \mathrm{~S} / \mathrm{Si}$ full cell offers promising application toward the development of high-energy LIBs.

\section{Electrolyte}

Electrolyte is also very important to cycling performance of Li-S batteries. For cyclo- $\mathrm{S}_{8}$, the polysulfides can chemically react with the carbonate-based electrolytes, so etherbased electrolytes are usually used. Furthermore, $\mathrm{LiNO}_{3}$ can form a passive film on the surface of lithium metal to prevent the reaction between polysulfides and $\mathrm{Li}$, so $\mathrm{LiNO}_{3}$ are usually used as an electrolyte additive to improve the Coulombic efficiency [106,107]. Hu's group [108] designed a new "solvent-in-salt" (SIS) electrolyte with $7 \mathrm{M}$ salt concentration. The SIS electrolyte inhibited the dissolution of lithium polysulfides, avoided the formation of lithium dendrites, and led to capacity retention of $74 \%$ after 100 cycles at $0.2 \mathrm{C}$.

Though the electrochemical performance of Li-S batteries is continuously improved, the sulfur content still needs to be increased. If the practical specific energy, volumetric energy density, and cycling performance are further enhanced, the Li-S batteries would bring a breakthrough to EESC devices.

\section{Li-O ${ }_{2}$ BATTERIES}

Recently, rechargeable $\mathrm{Li}-\mathrm{O}_{2}$ batteries have received a great deal of interest because of their high theoretical specific energy of $5,200 \mathrm{~W} \mathrm{~h} \mathrm{~kg}^{-1}$, which is 10 times larger than that of traditional LIBs with $\mathrm{LiCoO}_{2}$ /graphite couple [109,110]. Bruce and coworkers [111,112] proposed the reaction mechanism of $\mathrm{Li}_{-} \mathrm{O}_{2}$ batteries in nonaqueous electrolytes as follows:

oxygen reduction reaction (ORR):

$$
\begin{aligned}
& \mathrm{O}_{2}+\mathrm{e}^{-} \rightarrow \mathrm{O}_{2}^{-}, \\
& \mathrm{O}_{2}^{-}+\mathrm{Li}^{+} \rightarrow \mathrm{LiO}_{2}, \\
& 2 \mathrm{LiO}_{2} \rightarrow \mathrm{L}_{2} \mathrm{O}_{2}+\mathrm{O}_{2} ;
\end{aligned}
$$

oxygen evolution reaction (OER):

$$
\mathrm{L}_{2} \mathrm{O}_{2} \rightarrow 2 \mathrm{Li}^{+}+\mathrm{O}_{2}+2 \mathrm{e}^{-} \text {. }
$$

The theoretical potential of $\mathrm{Li}-\mathrm{O}_{2}$ batteries is $2.96 \mathrm{~V}$, but the practical discharge and charge potentials are $\sim 2.7$ and over $4.0 \mathrm{~V}$, respectively. The large overpotential is attributed to sluggish kinetics of ORR/OER. In addition, the discharge product (i.e., $\mathrm{Li}_{2} \mathrm{O}_{2}$ ) has poor conductivity and insolubility, which may completely cover the catalyst to prevent further reaction and increase the electrical resistance of air cathode, leading to low capacity and poor rate and cycling performance. To overcome the above problems, designing suitable cathode with large specific surface area, highly active catalysts, and porous nanostructure is very important.

The ORR/OER catalysts can be divided into three categories: carbon materials [113], noble metals or alloys [114-118], and metal oxides [119-127]. Table 2 lists the electrochemical performance of some representative catalysts for Li- $\mathrm{O}_{2}$ batteries. Kang's group [113] used hierarchically aligned porous carbon nanotube (CNT) fibril as the air electrode, which delivered a capacity of $1,700 \mathrm{~mA} \mathrm{~h} \mathrm{~g}^{-1}$ at a high current density of 5,000 $\mathrm{mA} \mathrm{g}^{-1}$. Peng et al. [115] developed a porous gold electrode with high capacity retention of $95 \%$ after 100 cycles at $500 \mathrm{~mA} \mathrm{~g}^{-1}$. Zhang and coworkers [119] prepared porous $\mathrm{La}_{0.75} \mathrm{Sr}_{0.25} \mathrm{MnO}_{3}$ nano- 
Table 2 Discharge capacity, cycling performance, and rate capability of $\mathrm{Li}-\mathrm{O}_{2}$ batteries with the representative catalysts

\begin{tabular}{|c|c|c|c|c|}
\hline Catalysts & $\begin{array}{c}\text { Maximum capacity based on } \\
\text { total mass }\end{array}$ & $\begin{array}{l}\text { Cycling performance/ } \\
\text { cutoff capacity }\end{array}$ & Rate capability & Ref. \\
\hline $\begin{array}{l}\text { 3D hierarchically aligned porous } \\
\text { CNT fibril }\end{array}$ & $\sim 3,000 \mathrm{~mA} \mathrm{~h} \mathrm{~g}^{-1}$ at $2,000 \mathrm{~mA} \mathrm{~g}^{-1}$ & 80 cycles $/ 1,000 \mathrm{~mA} \mathrm{~h} \mathrm{~g}^{-1}$ & $1,700 \mathrm{~mA} \mathrm{~h} \mathrm{~g}^{-1}$ at $5,000 \mathrm{~mA} \mathrm{~g}^{-1}$ & {$[113]$} \\
\hline Porous Au electrode & $\sim 320 \mathrm{~mA} \mathrm{~h} \mathrm{~g}^{-1}$ at $500 \mathrm{~mA} \mathrm{~g}^{-1}$ & $\begin{array}{l}\text { capacity retention of } 95 \% \\
\text { after } 100 \text { cycles }\end{array}$ & - & {$[115]$} \\
\hline $\begin{array}{l}\text { Ru@multi-walled carbon } \\
\text { nanotube paper }\end{array}$ & $22,600 \mathrm{~mA} \mathrm{~h} \mathrm{~g}^{-1}$ at $500 \mathrm{~mA} \mathrm{~g}^{-1}$ & 50 cycles $/ 5,000 \mathrm{~mA} \mathrm{~h} \mathrm{~g}^{-1}$ & - & {$[116]$} \\
\hline $\begin{array}{l}\text { Pd-modified hollow spherical } \\
\text { carbon/carbon paper }\end{array}$ & $12,254 \mathrm{~mA} \mathrm{~h} \mathrm{~g}^{-1}$ at $500 \mathrm{~mA} \mathrm{~g}^{-1}$ & 205 cycles $/ 1,000 \mathrm{~mA} \mathrm{~h} \mathrm{~g}^{-1}$ & $1,900 \mathrm{~mA} \mathrm{~h} \mathrm{~g}^{-1}$ at $800 \mathrm{~mA} \mathrm{~g}^{-1}$ & {$[118]$} \\
\hline Sponge-like $\boldsymbol{\varepsilon}-\mathrm{MnO}_{2}$ on $\mathrm{Ni}$ foam & $7,000 \mathrm{~mA} \mathrm{~h} \mathrm{~g}^{-1}$ at $100 \mathrm{~mA} \mathrm{~g}^{-1}$ & 100 cycles $/ 1,000 \mathrm{~mA} \mathrm{~h} \mathrm{~g}^{-1}$ & $1,900 \mathrm{~mA} \mathrm{~h} \mathrm{~g}^{-1}$ at $800 \mathrm{~mA} \mathrm{~g}^{-1}$ & {$[132]$} \\
\hline $\begin{array}{l}\text { Hierarchical porous } \boldsymbol{\varepsilon}-\mathrm{MnO}_{2} \\
\text { on } \mathrm{Ni} \text { foam }\end{array}$ & $5,700 \mathrm{~mA} \mathrm{~h} \mathrm{~g}^{-1}$ at $100 \mathrm{~mA} \mathrm{~g}^{-1}$ & 190 cycles/800 mA h g $\mathrm{g}^{-1}$ & $\sim 3,400 \mathrm{~mA} \mathrm{~h} \mathrm{~g}^{-1}$ at $800 \mathrm{~mA} \mathrm{~g}^{-1}$ & {$[28]$} \\
\hline Spinel $\mathrm{MnCo}_{2} \mathrm{O}_{4} /$ graphene hybrid & $3,784 \mathrm{~mA} \mathrm{~h} \mathrm{~g}^{-1}$ at $100 \mathrm{~mA} \mathrm{~g}^{-1}$ & 40 cycles $/ 1,000 \mathrm{~mA} \mathrm{~h} \mathrm{~g}^{-1}$ & $2,743 \mathrm{~mA} \mathrm{~h} \mathrm{~g}^{-1}$ at $800 \mathrm{~mA} \mathrm{~g}^{-1}$ & {$[120]$} \\
\hline $\begin{array}{l}\text { Porous perovskite } \mathrm{CaMnO}_{3} \\
\text { nanostructure }\end{array}$ & $\sim 3,670 \mathrm{~mA} \mathrm{~h} \mathrm{~g}^{-1}$ at $35 \mathrm{~mA} \mathrm{~g}^{-1}$ & 80 cycles $/ 500 \mathrm{~mA} \mathrm{~h} \mathrm{~g}_{\text {carbon }}{ }^{-1}$ & $\sim 1,830 \mathrm{~mA} \mathrm{~h} \mathrm{~g}^{-1}$ at $105 \mathrm{~mA} \mathrm{~g}^{-1}$ & {$[134]$} \\
\hline Porous perovskite $\mathrm{La}_{0.75} \mathrm{Sr}_{0.25} \mathrm{MnO}_{3}$ nanotubes & $\sim 11,000 \mathrm{~mA} \mathrm{~h} \mathrm{~g}^{-1}$ at $16.7 \mathrm{~mA} \mathrm{~g}^{-1}$ & 124 cycles $/ 1,000 \mathrm{~mA} \mathrm{~h} \mathrm{~g}^{-1}$ & $\sim 3,890 \mathrm{~mA} \mathrm{~h} \mathrm{~g}^{-1}$ at $133 \mathrm{~mA} \mathrm{~g}^{-1}$ & {$[119]$} \\
\hline
\end{tabular}

tubes (PNT-LSM) as an ORR/OER catalyst. The air electrode with PNT-LSM could be cycled over 124 cycles while the capacity was limited at $1,000 \mathrm{~mA} \mathrm{~h}^{-1}$. These reports demonstrated that $3 \mathrm{D}$ porous nanostructure is conducive to the electron and $\mathrm{O}_{2}$ transport, $\mathrm{Li}^{+}$diffusion, and restriction of $\mathrm{Li}_{2} \mathrm{O}_{2}$ growth, leading to excellent cycling and rate performance.

To decrease the charge potential, some soluble catalysts such as tetrathiafulvalene (TTF), LiI, and iron phthalocyanine $(\mathrm{FePc})$ are proposed [128-131]. Compared with solid catalysts, the soluble catalysts are more advantageous to catalyze the decomposition of $\mathrm{Li}_{2} \mathrm{O}_{2}$. Bruce's group [128] demonstrated that the TTF molecule was oxidized to form $\mathrm{TTF}^{+}$, and then $\mathrm{TTF}^{+}$reacted with the solid $\mathrm{Li}_{2} \mathrm{O}_{2}$ to be reduced back to TTF. The charge plateau could maintain at $3.5 \mathrm{~V}$ during 100 cycles at $1 \mathrm{~mA} \mathrm{~cm}^{-2}$. Wu's group [131] reported the use of an $\mathrm{I}_{3}^{-} / \mathrm{I}^{-}$redox couple to combine the photoelectrode of dye-sensitized solar cells with the oxygenelectrode $\mathrm{Li}-\mathrm{O}_{2}$ batteries. Through utilizing solar energy, the charge plateau decreased to $3.4 \mathrm{~V}$ at $0.032 \mathrm{~mA} \mathrm{~cm}^{-2}$. Sun et al. [129] found that FePc could serve as not only a ORR/OER catalyst but also a shuttle of $\left(\mathrm{O}_{2}\right)^{-}$species and electrons between the surface of the conductive carbon and the insulator $\mathrm{Li}_{2} \mathrm{O}_{2}$.

Among various ORR/OER catalysts, Mn-based oxides have attracted much interest because of their low cost, high abundance, environmental friendliness, and high catalytic activity. Our group synthesized a series of nanostructured $\mathrm{Mn}$-based oxides such as hierarchical porous $\varepsilon-\mathrm{MnO}_{2}$, spinel Co-Mn-O nanoparticles, and porous perovskite CaMn $\mathrm{O}_{3}$-Pt nanocomposite $[28,121,132-135]$. As shown in Fig. 9 , hierarchical porous $\varepsilon-\mathrm{MnO}_{2}$ on $\mathrm{Ni}$ foam was prepared by a facile electrodeposition method using oxygen as a bubble template [28]. The composite delivered discharge capacities of 5,700 $\mathrm{mA} \mathrm{h} \mathrm{g}^{-1}$ at $100 \mathrm{~mA} \mathrm{~g}^{-1}$ and $3,400 \mathrm{~mA} \mathrm{~h} \mathrm{~g}^{-1}$ at $800 \mathrm{~mA} \mathrm{~g}^{-1}$. When limiting the capacity to $800 \mathrm{~mA} \mathrm{~h} \mathrm{~g}^{-1}$, the terminal discharge voltage could exceed $2.2 \mathrm{~V}$ for 190 cycles at $500 \mathrm{~mA} \mathrm{~g}^{-1}$. We also investigated the size effect of $\mathrm{Li}_{2} \mathrm{O}_{2}$ on charge potential, and the small particle size facilitated the decrease of charge overpotential [136].

Besides catalysts, the electrolytes and anodes are also very important for the electrochemical performance of Li- $\mathrm{O}_{2}$ batteries [112], but only a few reports focus on this aspect. Furthermore, the experimental capacity of $\mathrm{Li}-\mathrm{O}_{2}$ batteries is calculated based on the mass of catalysts. This method makes it very difficult to compare different systems, and the real specific energy and energy density are also difficult to determine. How to find a reasonable evaluation method is what we should discuss in the future.

\section{CONCLUSIONS AND OUTLOOK}

A series of electrode materials have been applied for LIBs with multi-electron reaction and $\mathrm{Li}$-S batteries, and various catalysts have been attempted to promote the two-electron reaction of $\mathrm{Li}-\mathrm{O}_{2}$ batteries. The strategies to improve practical capacity, cycling and rate performance have also been widely studied. Generally, Li rechargeable batteries with multi-electron reaction can obtain a capacity of more than $200 \mathrm{~mA} \mathrm{~h} \mathrm{~g}^{-1}$ for the active material. Furthermore, nanostructured materials facilitate both electronic transport and ionic diffusion, leading to high rate performance. Thus, combining nanomaterials with multi-electron reaction is the research direction in the future.

For cathodes of LIBs, silicate-type $\mathrm{Li}_{2} \mathrm{MnSiO}_{4}$ possesses a high theoretical specific capacity of $\sim 333 \mathrm{~mA} \mathrm{~h} \mathrm{~g}^{-1}$ via a two-electron reaction, but it is plagued by low conduc- 

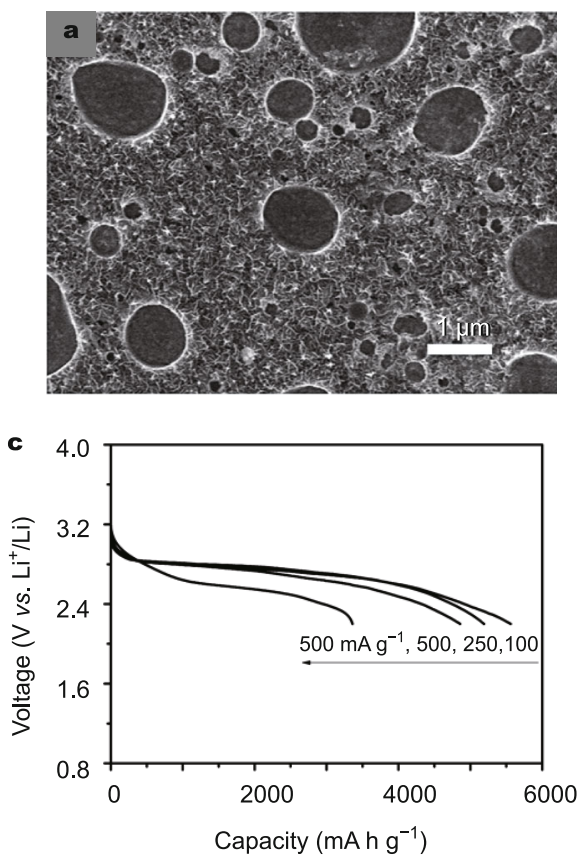

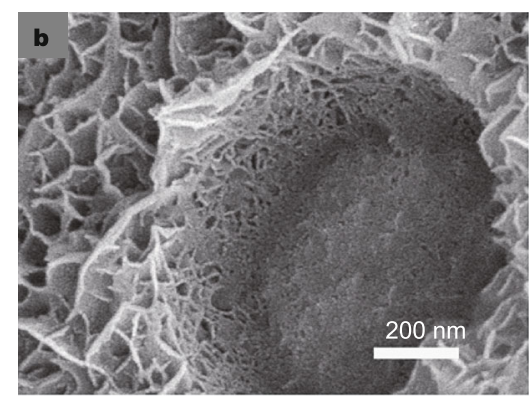

d

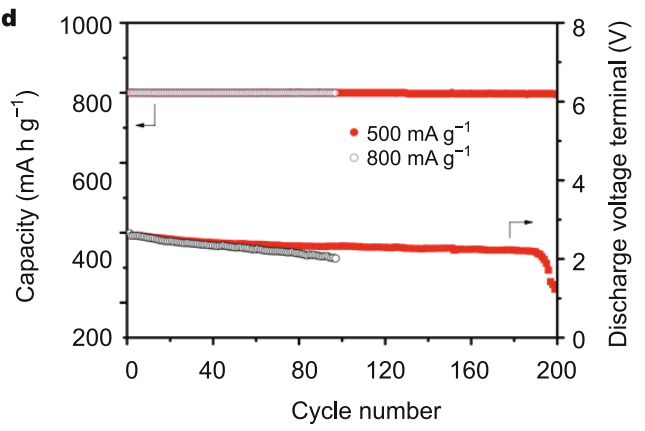

Figure 9 (a, b) SEM images of hierarchical porous $\mathcal{\varepsilon}-\mathrm{MnO}_{2}$ at different scales; (c) rate performance of hierarchical porous $\mathcal{\varepsilon}$-MnO; $(\mathrm{d})$ variation of terminal discharge voltage on cycling at current densities of 500 and $800 \mathrm{~mA} \mathrm{~g}^{-1}$. Reprinted with permission from Ref. [28]. Copyright 2014, Wiley-VCH.

tivity and poor structural stability. Although the surface coating and downsizing the particle size partially relieve the problems, it cannot absolutely solve its low intrinsic conductivity. Doping other cations or anions may enhance the structural stability and $\mathrm{Li}^{+}$diffusion kinetics. Core-shell structured $\mathrm{Li}_{2} \mathrm{MnSiO}_{4} @ \mathrm{C}$ nanocomposites have delivered great improvements on the rate and cycling performance. However, only a few reports focus on increasing the operation potential of $\mathrm{Li}_{2} \mathrm{MnSiO}_{4}$ by cation doping such as $\mathrm{Co}$ and Ni. As to anodes of LIBs, most inorganic anode materials can achieve multi-electron reaction to obtain high capacity, but their volume change is huge, leading to poor cycling performance. Nanostructured anode materials with surface modification have improved the electrochemical performance, which offers a great promise for next-generation LIBs with high energy. Recently, organic LIBs have attracted a lot of attention because of high electron transfer number and low molecular weight of organic electrode materials. Nevertheless, the low conductivity and easy dissolution in organic electrolytes limit their development. Using lithium salts of organic carbonyl compounds combined with highly conductive carbon materials are promising in the applications of green organic LIBs.

For Li-S batteries, C/S nanocomposite and ether-based electrolytes have been widely used as cathodes and electrolytes. However, low sulfur content in the electrodes decreases thire practical specific energy, and expensive ether-based electrolytes increase the cost. If nano $\mathrm{S}$ is di- rectly loaded on the $3 \mathrm{D}$ porous current collector (e.g., carbon paper), the specific energy would be improved greatly. Small sulfur molecules with carbonate-based electrolytes and $\mathrm{Li}_{2} \mathrm{~S}$ coupled with $\mathrm{Si}$ or $\mathrm{Sn}$ anode are also promising research directions.

For Li- $\mathrm{O}_{2}$ batteries, extensive fundamental studies focus on using highly active catalysts to improve the sluggish kinetics. Mn-based oxides along with various 3D porous nanostructures are particularly attractive. Compared with the discharge mechanism, the charge process is more difficult to understand, so more in-situ characterizations should be used to observe the charge process. In addition, learning from nature may help us to find more suitable structures to achieve highly effective and fast ORR/OER since biology embodies such characteristics.

Improving the operation potential of multi-electron reaction and volumetric energy density of Li rechargeable batteries should be the focus of future studies. Great opportunities and challenges still coexist in electrode materials with multi-electron reaction.

Received 20 October 2014; accepted 11 November 2014; published online 17 December 2014

1 Dunn B, Kamath H, Tarascon JM. Electrical energy storage for the grid: a battery of choices. Science, 2011, 334: 928-935

2 Goodenough JB. Evolution of strategies for modern rechargeable batteries. Acc Chem Res, 2012, 46: 1053-1061

3 Cheng F, Liang J, Tao Z, Chen J. Functional materials for recharge- 
able batteries. Adv Mater, 2011, 23: 1695-1715

4 Chen J, Cheng F. Combination of lightweight elements and nanostructured materials for batteries. Acc Chem Res, 2009, 42: 713-723

5 Zhang K, Han X, Hu Z, et al. Nanostructured Mn-based oxides for electrochemical energy storage and conversion. Chem Soc Rev, doi: $10.1039 / \mathrm{C} 4 \mathrm{CS} 00218 \mathrm{~K}$

6 Tao Z, Chen J. Secondary battery systems for energy storage in smart grids. Chin Sci Bull, 2012, 57: 2545-2560

7 Song HK, Lee KT, Kim MG, Nazar LF, Cho J. Recent progress in nanostructured cathode materials for lithium secondary batteries. Adv Funct Mater, 2010, 20: 3818-3834

8 Zhou Z, Tian N, Li J, Broadwell I, Sun S. Nanomaterials of high surface energy with exceptional properties in catalysis and energy storage. Chem Soc Rev, 2011, 40: 4167-4185

9 Bruce PG, Freunberger SA, Hardwick LJ, Tarascon JM. Li- $\mathrm{O}_{2}$ and Li-S batteries with high energy storage. Nat Mater, 2012, 11: 19-29

10 Wang Y, Li H, He P, Hosono E, Zhou H. Nano active materials for lithium-ion batteries. Nanoscale, 2010, 2: 1294-1305

11 Liu J, Wen Y, Wang Y, et al. Carbon-encapsulated pyrite as stable and earth-abundant high energy cathode material for rechargeable lithium batteries. Adv Mater, 2014, 26: 6025-6030

12 Zhang K, Zhao Q, Tao Z, Chen J. Composite of sulfur impregnated in porous hollow carbon spheres as the cathode of Li-S batteries with high performance. Nano Res, 2013, 6: 38-46

13 Duan W, Hu Z, Zhang K, et al. $\mathrm{Li}_{3} \mathrm{~V}_{2}\left(\mathrm{PO}_{4}\right)_{3} @ \mathrm{C}$ core-shell nanocomposite as a superior cathode material for lithium-ion batteries. $\mathrm{Na}$ noscale, 2013, 5: 6485-6490

14 Gong Z, Yang Y. Recent advances in the research of polyanion-type cathode materials for Li-ion batteries. Energy Environ Sci, 2011, 4: 3223-3242

15 Gao $\mathrm{H}, \mathrm{Hu} \mathrm{Z}$, Zhang $\mathrm{K}$, Cheng $\mathrm{F}$, Chen J. Intergrown $\mathrm{Li}_{2} \mathrm{FeSiO}_{4}$. $\mathrm{LiFePO}_{4}$-C nanocomposites as high-capacity cathode materials for lithium-ion batteries. Chem Commun, 2013, 49: 3040-3042

$16 \mathrm{Hu} \mathrm{Z}$, Zhang K, Gao H, et al. $\mathrm{Li}_{2} \mathrm{MnSiO}_{4} @ \mathrm{C}$ nanocomposite as a high-capacity cathode material for Li-ion batteries. J Mater Chem A, 2013, 1: 12650-12656

17 Zhang K, Wang L, Hu Z, Cheng F, Chen J. Ultrasmall $\mathrm{Li}_{2} \mathrm{~S}$ nanoparticles anchored in graphene nanosheets for high-energy lithium-ion batteries. Sci Rep, 2014, 4: 6467

18 Zhu Z, Wang S, Du J, et al. Ultrasmall Sn nanoparticles embedded in nitrogen-doped porous carbon as high-performance anode for lithium-ion batteries. Nano Lett, 2013, 14: 153-157

19 Wu H, Chan G, Choi JW, et al. Stable cycling of double-walled silicon nanotube battery anodes through solid-electrolyte interphase control. Nat Nanotech, 2012, 7: 310-315

$20 \mathrm{Ma} \mathrm{H}$, Cheng F, Chen J, et al. Nest-like silicon nanospheres for high-capacity lithium storage. Adv Mater, 2007, 19: 4067-4070

21 Wang L, He X, Li J, et al. Nano-structured phosphorus composite as high-capacity anode materials for lithium batteries. Angew Chem Int Ed, 2012, 51: 9034-9037

22 Chen J, Xu L, Li W, Gou X. $\alpha-\mathrm{Fe}_{2} \mathrm{O}_{3}$ nanotubes in gas sensor and lithium-ion battery applications. Adv Mater, 2005, 17: 582-586

$23 \mathrm{Xu}$ X, Cao R, Jeong S, Cho J. Spindle-like mesoporous $\alpha-\mathrm{Fe}_{2} \mathrm{O}_{3}$ anode material prepared from MOF template for high-rate lithium batteries. Nano Lett, 2012, 12: 4988-4991

24 Zhu Z, Cheng $\mathrm{F}$, Chen J. Investigation of effects of carbon coating on the electrochemical performance of $\mathrm{Li}_{4} \mathrm{Ti}_{5} \mathrm{O}_{12} / \mathrm{C}$ nanocomposites. J Mater Chem A, 2013, 1: 9484-9490

25 Wang $\mathrm{S}$, Wang $\mathrm{L}$, Zhang $\mathrm{K}$, et al. Organic $\mathrm{Li}_{4} \mathrm{C}_{8} \mathrm{H}_{2} \mathrm{O}_{6}$ nanosheets for lithium-ion batteries. Nano Lett, 2013, 13: 4404-4409

26 Liang Y, Zhang P, Chen J. Function-oriented design of conjugated carbonyl compound electrodes for high energy lithium batteries. Chem Sci, 2013, 4: 1330-1337

27 Huang W, Zhu Z, Wang L, et al. Quasi-solid-state rechargeable lithium-ion batteries with a calix[4]quinone cathode and gel polymer electrolyte. Angew Chem Int Ed, 2013, 52: 9162-9166

28 Hu X, Cheng F, Han X, Zhang T, Chen J. Oxygen bubble-templated hierarchical porous $\varepsilon-\mathrm{MnO}_{2}$ as a superior catalyst for rechargeable Li-O batteries. Small, doi: 10.1002/smll.201401790

29 Nytén A, Abouimrane A, Armand M, Gustafsson T, Thomas JO. Electrochemical performance of $\mathrm{Li}_{2} \mathrm{FeSiO}_{4}$ as a new Li-battery cathode material. Electrochem Commun, 2005, 7: 156-160

30 Boulineau A, Sirisopanaporn C, Dominko R, et al. Polymorphism and structural defects in $\mathrm{Li}_{2} \mathrm{FeSiO}_{4}$. Dalton Trans, 2010, 39: 63106316

31 Sirisopanaporn C, Masquelier C, Bruce PG, Armstrong AR, Dominko R. Dependence of $\mathrm{Li}_{2} \mathrm{FeSiO}_{4}$ electrochemistry on structure. J Am Chem Soc, 2010, 133: 1263-1265

32 Zheng $\mathrm{Z}$, Wang $\mathrm{Y}$, Zhang $\mathrm{A}$, et al. Porous $\mathrm{Li}_{2} \mathrm{FeSiO}_{4} / \mathrm{C}$ nanocomposite as the cathode material of lithium-ion batteries. J Power Sources, 2012, 198: 229-235

33 Gao $\mathrm{H}, \mathrm{Hu} \mathrm{Z}$, Zhang $\mathrm{K}$, et al. Hydrothermal synthesis of spindle-like $\mathrm{Li}_{2} \mathrm{FeSiO}_{4}$-C composite as cathode materials for lithium-ion batteries. J Energy Chem, 2014, 23: 274-281

34 Zhu H, Wu X, Zan L, Zhang Y. Three-dimensional macroporous graphene- $\mathrm{Li}_{2} \mathrm{FeSiO}_{4}$ composite as cathode material for lithium-ion batteries with superior electrochemical performances. ACS Appl Mater Interfaces, 2014, 6: 11724-11733

35 Gao H, Hu Z, Yang J, Chen J. $\mathrm{Li}_{2-x} \mathrm{Fe}_{1-x} \mathrm{Al}_{x} \mathrm{SiO}_{4} / \mathrm{C}$ nanocomposites cathodes for lithium-ion batteries. Energy Technol, 2014, 2: 355 361

36 Nyten A, Kamali S, Haggstrom L, Gustafsson T, Thomas JO. The lithium extraction/insertion mechanism in $\mathrm{Li}_{2} \mathrm{FeSiO}_{4}$. J Mater Chem, 2006, 16: 2266-2272

37 Yi J, Hou $\mathrm{M}$, Bao $\mathrm{H}$, et al. In-situ generation of $\mathrm{Li}_{2} \mathrm{FeSiO}_{4} / \mathrm{C}$ nanocomposite as cathode material for lithium ion battery. Electrochim Acta, 2014, 133: 564-569

38 Jiang $\mathrm{X}, \mathrm{Xu} \mathrm{H}$, Liu J, et al. Hierarchical mesoporous $\mathrm{Li}_{2} \mathrm{Mn}_{0.5} \mathrm{Fe}_{0.5}$ $\mathrm{SiO}_{4}$ and $\mathrm{Li}_{2} \mathrm{Mn}_{0.5} \mathrm{Fe}_{0.5} \mathrm{SiO}_{4} / \mathrm{C}$ assembled by nanoparticles or nanoplates as a cathode material for lithium-ion batteries. Nano Energy, 2014, 7: 1-9

39 Fisher CAJ, Kuganathan N, Islam MS. Defect chemistry and lithium-ion migration in polymorphs of the cathode material $\mathrm{Li}_{2} \mathrm{Mn}$ $\mathrm{SiO}_{4}$. J Mater Chem A, 2013, 1: 4207-4214

40 Duncan H, Kondamreddy A, Mercier PHJ, et al. Novel Pn polymorph for $\mathrm{Li}_{2} \mathrm{MnSiO}_{4}$ and its electrochemical activity as a cathode material in Li-ion batteries. Chem Mater, 2011, 23: 5446-5456

41 Arroyo-deDompablo ME, Dominko R, Gallardo-Amores JM, et al On the energetic stability and electrochemistry of $\mathrm{Li}_{2} \mathrm{MnSiO}_{4}$ polymorphs. Chem Mater, 2008, 20: 5574-5584

42 Zhang $\mathrm{S}$, Lin $\mathrm{Z}$, Ji L, et al. Cr-doped $\mathrm{Li}_{2} \mathrm{MnSiO}_{4} /$ carbon composite nanofibers as high-energy cathodes for Li-ion batteries. J Mater Chem, 2012, 22: 14661-14666

43 Liu J, Xu H, Jiang X, Yang J, Qian Y. Facile solid-state synthesis of $\mathrm{Li}_{2} \mathrm{MnSiO}_{4} / \mathrm{C}$ nanocomposite as a superior cathode with a long cycle life. J Power Sources, 2013, 231: 39-43

$44 \mathrm{He}$ G, Manthiram A. Nanostructured $\mathrm{Li}_{2} \mathrm{MnSiO}_{4} / \mathrm{C}$ cathodes with hierarchical macro-/mesoporosity for lithium-ion batteries. Adv Funct Mater, 2014, 24: 5277-5283

$45 \mathrm{Li} \mathrm{Y}$, Gong Z, Yang Y. Synthesis and characterization of $\mathrm{Li}_{2} \mathrm{Mn}$ $\mathrm{SiO}_{4} / \mathrm{C}$ nanocomposite cathode material for lithium ion batteries. J Power Sources, 2007, 174: 528-532

46 Gaubicher J, Wurm C, Goward G, Masquelier C, Nazar L. Rhombohedral form of $\mathrm{Li}_{3} \mathrm{~V}_{2}\left(\mathrm{PO}_{4}\right)_{3}$ as a cathode in $\mathrm{Li}$-ion batteries. Chem Mater, 2000, 12: 3240-3242

47 Huang H, Yin SC, Kerr T, Taylor N, Nazar LF. Nanostructured composites: a high capacity, fast rate $\mathrm{Li}_{3} \mathrm{~V}_{2}\left(\mathrm{PO}_{4}\right)_{3} /$ carbon cathode for rechargeable lithium batteries. Adv Mater, 2002, 14: 1525-1528

48 Yin SC, Grondey H, Strobel P, Huang H, Nazar LF. Charge ordering in lithium vanadium phosphates: electrode materials for lithi- 
um-ion batteries. J Am Chem Soc, 2003, 125: 326-327

49 Yin SC, Grondey H, Strobel P, Anne M, Nazar LF. Electrochemical property: structure relationships in monoclinic $\mathrm{Li}_{3-\mathrm{y}} \mathrm{V}_{2}\left(\mathrm{PO}_{4}\right)_{3}$. J Am Chem Soc, 2003, 125: 10402-10411

50 Li D, Tian M, Xie R, et al. Three-dimensionally ordered macroporous $\mathrm{Li}_{3} \mathrm{~V}_{2}\left(\mathrm{PO}_{4}\right)_{3} / \mathrm{C}$ nanocomposite cathode material for high-capacity and high-rate Li-ion batteries. Nanoscale, 2014, 6: 3302-3308

51 Zhu X, Yan Z, Wu W, et al. Manipulating size of $\mathrm{Li}_{3} \mathrm{~V}_{2}\left(\mathrm{PO}_{4}\right)_{3}$ with reduced graphene oxide: towards high-performance composite cathode for lithium ion batteries. Sci Rep, 2014, 4: 5768

52 Wu H, Cui Y. Designing nanostructured Si anodes for high energy lithium ion batteries. Nano Today, 2012, 7: 414-429

53 Ge M, Lu Y, Ercius P, et al. Large-scale fabrication, 3D tomography, and lithium-ion battery application of porous silicon. Nano Lett, 2013, 14: 261-268

54 Kim H, Han B, Choo J, Cho J. Three-dimensional porous silicon particles for use in high-performance lithium secondary batteries. Angew Chem Int Ed, 2008, 47: 10151-10154

$55 \mathrm{Ng} \mathrm{SH}$, Wang J, Wexler D, et al. Highly reversible lithium storage in spheroidal carbon-coated silicon nanocomposites as anodes for lithium-ion batteries. Angew Chem Int Ed, 2006, 45: 6896-6899

$56 \mathrm{Du}$ F, Li B, Fu W, et al. Surface binding of polypyrrole on porous silicon hollow nanospheres for Li-ion battery anodes with high structure stability. Adv Mater, 2014, 26: 6145-6150

$57 \mathrm{Xu} \mathrm{Y,} \mathrm{Zhu} \mathrm{Y,} \mathrm{Han} \mathrm{F,} \mathrm{Luo} \mathrm{C,} \mathrm{Wang} \mathrm{C.} \mathrm{3D} \mathrm{Si/C} \mathrm{fiber} \mathrm{paper} \mathrm{electrodes}$ fabricated using a combined electrospray/electrospinning technique for Li-ion batteries. Adv Energy Mater, doi: 10.1002/aenm. 201400753

58 Li H, Bai H, Tao Z, Chen J. Si-Y multi-layer thin films as anode materials of high-capacity lithium-ion batteries. J Power Sources, 2012, 217: 102-107

59 Guo S, Li H, Bai H, Tao Z, Chen J. Ti/Si/Ti sandwich-like thin film as the anode of lithium-ion batteries. J Power Sources, 2014, 248 : 1141-1148

60 Hassoun J, Derrien G, Panero S, Scrosati B. A nanostructured Sn-C composite lithium battery electrode with unique stability and high electrochemical performance. Adv Mater, 2008, 20: 3169-3175

61 Zhang W, Hu J, Guo Y, et al. Tin-nanoparticles encapsulated in elastic hollow carbon spheres for high-performance anode material in lithium-ion batteries. Adv Mater, 2008, 20: 1160-1165

$62 \mathrm{Xu} \mathrm{Y,} \mathrm{Liu} \mathrm{Q,} \mathrm{Zhu} \mathrm{Y,} \mathrm{et} \mathrm{al.} \mathrm{Uniform} \mathrm{nano-Sn/C} \mathrm{composite} \mathrm{anodes} \mathrm{for}$ lithium ion batteries. Nano Lett, 2013, 13: 470-474

63 Kim MG, Sim S, Cho J. Novel core-shell Sn-Cu anodes for lithium rechargeable batteries prepared by a redox-transmetalation reaction. Adv Mater, 2010, 22: 5154-5158

64 Ke F, Huang L, Jamison L, et al. Nanoscale tin-based intermetallic electrodes encapsulated in microporous copper substrate as the negative electrode with a high rate capacity and a long cycleability for lithium-ion batteries. Nano Energy, 2013, 2: 595-603

65 Zhang N, Zhao Q, Han X, Yang J, Chen J. Pitaya-like Sn@C nanocomposites as high-rate and long-life anode for lithium-ion batteries. Nanoscale, 2014, 6: 2827-2832

66 Qian J, Qiao D, Ai X, Cao Y, Yang H. Reversible 3-Li storage reactions of amorphous phosphorus as high capacity and cycling-stable anodes for Li-ion batteries. Chem Commun, 2012, 48: 8931-8933

67 Park CM, Sohn HJ. Black phosphorus and its composite for lithium rechargeable batteries. Adv Mater, 2007, 19: 2465-2468

68 Cabana J, Monconduit L, Larcher D, Palacín MR. Beyond intercalation-based Li-ion batteries: the state of the art and challenges of electrode materials reacting through conversion reactions. Adv Mater, 2010, 22: E170-E192

$69 \mathrm{Li}$ WY, Xu LN, Chen J. $\mathrm{Co}_{3} \mathrm{O}_{4}$ nanomaterials in lithium-ion batteries and gas sensors. Adv Funct Mater, 2005, 15: 851-857

70 Sun Y, Hu X, Luo W, Xia F, Huang Y. Reconstruction of conformal nanoscale $\mathrm{MnO}$ on graphene as a high-capacity and long-life an- ode material for lithium ion batteries. Adv Funct Mater, 2013, 23: 2436-2444

71 Chen $\mathrm{S}$, Xin $\mathrm{Y}$, Zhou Y, et al. Self-supported $\mathrm{Li}_{4} \mathrm{Ti}_{5} \mathrm{O}_{12}$ nanosheet arrays for lithium ion batteries with excellent rate capability and ultralong cycle life. Energy Environ Sci, 2014, 7: 1924-1930

72 Feckl JM, Fominykh K, Döblinger M, Fattakhova-Rohlfing D, Bein T. Nanoscale porous framework of lithium titanate for ultrafast lithium insertion. Angew Chem Int Ed, 2012, 51: 7459-7463

$73 \mathrm{Yu} \mathrm{L}, \mathrm{Wu} \mathrm{HB}$, Lou XW. Mesoporous $\mathrm{Li}_{4} \mathrm{Ti}_{5} \mathrm{O}_{12}$ hollow spheres with enhanced lithium storage capability. Adv Mater, 2013, 25: 22962300

74 Zhao L, Hu Y, Li H, Wang Z, Chen L. Porous $\mathrm{Li}_{4} \mathrm{Ti}_{5} \mathrm{O}_{12}$ coated with $\mathrm{N}$-doped carbon from ionic liquids for $\mathrm{Li}$-ion batteries. Adv Mater, 2011, 23: 1385-1388

75 Wang Y, Gu L, Guo Y, et al. Rutile- $\mathrm{TiO}_{2}$ nanocoating for a high-rate $\mathrm{Li}_{4} \mathrm{Ti}_{5} \mathrm{O}_{12}$ anode of a lithium-ion battery. J Am Chem Soc, 2012, 134 7874-7879

76 Liu J, Song K, van Aken PA, Maier J, Yu Y. Self-supported $\mathrm{Li}_{4} \mathrm{Ti}_{5} \mathrm{O}_{12}-$ $\mathrm{C}$ nanotube arrays as high-rate and long-life anode materials for flexible Li-ion batteries. Nano Lett, 2014, 14: 2597-2603

77 Liang Y, Tao Z, Chen J. Organic electrode materials for rechargeable lithium batteries. Adv Energy Mater, 2012, 2: 742-769

78 Wang S, Tao Z, Chen J. Organic conjugated carbonyl compounds as electrode materials for lithium-ion batteries. Chin Sci Bull, 2013, 58: 3132-3139

79 Liang Y, Zhang P, Yang S, Tao Z, Chen J. Fused heteroaromatic organic compounds for high-power electrodes of rechargeable lithium batteries. Adv Energy Mater, 2013, 3: 600-605

80 Nokami T, Matsuo T, Inatomi Y, et al. Polymer-bound pyrene-4, 5,9,10-tetraone for fast-charge and -discharge lithium-ion batteries with high capacity. J Am Chem Soc, 2012, 134: 19694-19700

81 Chen H, Armand M, Courty M, et al. Lithium salt of tetrahydroxybenzoquinone: toward the development of a sustainable Li-ion battery. J Am Chem Soc, 2009, 131: 8984-8988

82 Armand $\mathrm{M}$, Grugeon S, Vezin $\mathrm{H}$, et al. Conjugated dicarboxylate anodes for Li-ion batteries. Nat Mater, 2009, 8: 120-125

83 Zhu Z, Guo D, Tao Z, Chen J. Pillar[5]quinone as cathode material for quasi-solid-state rechargeable lithium batteries. Sci Sin Chim, 2014, 44: 1175-1180

84 Li H, Duan W, Zhao Q, et al. 2,2'-Bis(3-hydroxy-1,4-naphthoquinone)/CMK-3 nanocomposite as cathode material for lithium-ion batteries. Inorg Chem Front, 2014, 1: 193-199

85 Song $\mathrm{Z}, \mathrm{Xu} \mathrm{T}$, Gordin $\mathrm{ML}$, et al. Polymer-graphene nanocomposites as ultrafast-charge and-discharge cathodes for rechargeable lithium batteries. Nano Lett, 2012, 12: 2205-2211

86 Ji X, Lee KT, Nazar LF. A highly ordered nanostructured carbonsulphur cathode for lithium-sulphur batteries. Nat Mater, 2009, 8: 500-506

87 Gao J, Lowe MA, Kiya Y, Abruña HD. Effects of liquid electrolytes on the charge-discharge performance of rechargeable lithium/sulfur batteries: electrochemical and in-situ X-ray absorption spectroscopic studies. J Phys Chem C, 2011, 115: 25132-25137

88 Yang Y, Zheng G, Cui Y. Nanostructured sulfur cathodes. Chem Soc Rev, 2013, 42: 3018-3032

89 Yin Y, Xin S, Guo Y, Wan L. Lithium-sulfur batteries: electrochemistry, materials, and prospects. Angew Chem Int Ed, 2013, 52: 13186-13200

90 Jayaprakash N, Shen J, Moganty SS, Corona A, Archer LA. Porous hollow carbon@sulfur composites for high-power lithium-sulfur batteries. Angew Chem Int Ed, 2011, 50: 5904-5908

91 Yang X, Zhang L, Zhang F, Huang Y, Chen Y. Sulfur-infiltrated graphene-based layered porous carbon cathodes for high-performance lithium-sulfur batteries. ACS Nano, 2014, 8: 5208-5215

92 Elazari R, Salitra G, Garsuch A, Panchenko A, Aurbach D. Sulfur-impregnated activated carbon fiber cloth as a binder-free cathode for rechargeable Li-S batteries. Adv Mater, 2011, 23: 5641-5644 
93 Chen S, Huang X, Liu H, et al. 3D hyperbranched hollow carbon nanorod architectures for high-performance lithium-sulfur batteries. Adv Energy Mater, doi: 10.1002/aenm.201301761

94 Yang Y, Yu G, Cha JJ, et al. Improving the performance of lithiumsulfur batteries by conductive polymer coating. ACS Nano, 2011, 5: 9187-9193

95 Fu Y, Manthiram A. Enhanced cyclability of lithium-sulfur batteries by a polymer acid-doped polypyrrole mixed ionic-electronic conductor. Chem Mater, 2012, 24: 3081-3087

96 Li W, Zhang Q, Zheng G, et al. Understanding the role of different conductive polymers in improving the nanostructured sulfur cathode performance. Nano Lett, 2013, 13: 5534-5540

97 Wang L, He X, Li J, et al. Analysis of the synthesis process of sulphur-poly(acrylonitrile)-based cathode materials for lithium batteries. J Mater Chem, 2012, 22: 22077-22081

98 Yin L, Wang J, Lin F, Yang J, Nuli Y. Polyacrylonitrile/graphene composite as a precursor to a sulfur-based cathode material for high-rate rechargeable Li-S batteries. Energy Environ Sci, 2012, 5 6966-6972

99 Xin S, Gu L, Zhao N, et al. Smaller sulfur molecules promise better lithium-sulfur batteries. J Am Chem Soc, 2012, 134: 18510-18513

100 Li Z, Jiang Y, Yuan L, et al. A highly ordered meso@microporous carbon-supported sulfur@smaller sulfur core-shell structured cathode for Li-S batteries. ACS Nano, 2014, 8: 9295-9303

101 Yang Y, McDowell MT, Jackson A, et al. New nanostructured $\mathrm{Li}_{2} \mathrm{~S} /$ silicon rechargeable battery with high specific energy. Nano Lett, 2010, 10: 1486-1491

102 Fu Y, Su Y-S, Manthiram A. Li S-carbon sandwiched electrodes with superior performance for lithium-sulfur batteries. Adv Energy Mater, doi: 10.1002/aenm.201300655

103 Seh ZW, Wang H, Hsu PC, et al. Facile synthesis of $\mathrm{Li}_{2} \mathrm{~S}$-polypyrrole composite structures for high-performance $\mathrm{Li}_{2} \mathrm{~S}$ cathodes. Energy Environ Sci, 2014, 7: 672-676

104 Nan C, Lin Z, Liao H, et al. Durable carbon-coated Li S core-shell spheres for high performance lithium/sulfur cells. J Am Chem Soc, 2014, 136: 4659-4663

105 Cai K, Song MK, Cairns EJ, Zhang Y. Nanostructured $\mathrm{Li}_{2} \mathrm{~S}-\mathrm{C}$ composites as cathode material for high-energy lithium/sulfur batteries. Nano Lett, 2012, 12: 6474-6479

106 Yang Y, Zheng G, Misra S, et al. High-capacity micrometer-sized $\mathrm{Li}_{2} \mathrm{~S}$ particles as cathode materials for advanced rechargeable lithium-ion batteries. J Am Chem Soc, 2012, 134: 15387-15394

107 Aurbach D, Pollak E, Elazari R, et al. On the surface chemical aspects of very high energy density, rechargeable Li-sulfur batteries. J Electrochem Soc, 2009, 156: A694-A702

108 Suo L, Hu Y, Li H, Armand M, Chen L. A new class of Solvent-inSalt electrolyte for high-energy rechargeable metallic lithium batteries. Nat Commun, 2013, 4: 1481

109 Wang Z, Xu D, Xu J, Zhang X. Oxygen electrocatalysts in metal-air batteries: from aqueous to nonaqueous electrolytes. Chem Soc Rev, 2014, 43: 7746-7786

110 Cheng F, Chen J. Nanoporous catalysts for rechargeable Li-air batteries. Acta Chim Sin, 2013, 71: 473-477

111 Peng Z, Freunberger SA, Hardwick LJ, et al. Oxygen reactions in a non-aqueous $\mathrm{Li}^{+}$electrolyte. Angew Chem Int Ed, 2011, 50: 63516355

112 Cheng F, Chen J. Metal-air batteries: from oxygen reduction electrochemistry to cathode catalysts. Chem Soc Rev, 2012, 41: 2172-2192

113 Lim HD, Park KY, Song H, et al. Enhanced power and rechargeability of a Li-O $\mathrm{O}_{2}$ battery based on a hierarchical-fibril CNT electrode. Adv Mater, 2013, 25: 1348-1352

114 Lu Y, Gasteiger HA, Shao-Horn Y. Catalytic activity trends of oxygen reduction reaction for nonaqueous Li-air batteries. J Am Chem Soc, 2011, 133: 19048-19051

115 Peng Z, Freunberger SA, Chen Y, Bruce PG. A reversible and hig- her-rate Li-O battery. Science, 2012, 337: 563-566

116 Li F, Chen Y, Tang DM, et al. Performance-improved $\mathrm{Li}_{-} \mathrm{O}_{2}$ battery with $\mathrm{Ru}$ nanoparticles supported on binder-free multi-walled carbon nanotube paper as cathode. Energy Environ Sci, 2014, 7: 1648-1652

117 Du J, Cheng F, Wang S, Zhang T, Chen J. M(Salen)-derived nitrogen-doped $\mathrm{M} / \mathrm{C}(\mathrm{M}=\mathrm{Fe}, \mathrm{Co}, \mathrm{Ni})$ porous nanocomposites for electrocatalytic oxygen reduction. Sci Rep, 2014, 4: 4386

$118 \mathrm{Xu}$ J, Wang Z, Xu D, Zhang L, Zhang X. Tailoring deposition and morphology of discharge products towards high-rate and long-life lithium-oxygen batteries. Nat Commun, 2013, 4: 2438

$119 \mathrm{Xu} \mathrm{J}, \mathrm{Xu} \mathrm{D}$, Wang Z, et al. Synthesis of perovskite-based porous $\mathrm{La}_{0.75} \mathrm{Sr}_{0.25} \mathrm{MnO}_{3}$ nanotubes as a highly efficient electrocatalyst for rechargeable lithium-oxygen batteries. Angew Chem Int Ed, 2013, 52: 3887-3890

120 Wang $\mathrm{H}$, Yang Y, Liang $\mathrm{Y}$, et al. Rechargeable $\mathrm{Li}-\mathrm{O}_{2}$ batteries with a covalently coupled $\mathrm{MnCo}_{2} \mathrm{O}_{4}$-graphene hybrid as an oxygen cathode catalyst. Energy Environ Sci, 2012, 5: 7931-7935

121 Cheng F, Shen J, Peng B, et al. Rapid room-temperature synthesis of nanocrystalline spinels as oxygen reduction and evolution electrocatalysts. Nat Chem, 2011, 3: 79-84

122 Cheng F, Zhang T, Zhang Y, et al. Enhancing electrocatalytic oxygen reduction on $\mathrm{MnO}_{2}$ with vacancies. Angew Chem Int Ed, 2013, 52: 2474-2477

123 Han X, Zhang T, Du J, Cheng F, Chen J. Porous calcium-manganese oxide microspheres for electrocatalytic oxygen reduction with high activity. Chem Sci, 2013, 4: 368-376

124 Liang Y, Wang H, Zhou J, et al. Covalent hybrid of spinel manganese-cobalt oxide and graphene as advanced oxygen reduction electrocatalysts. J Am Chem Soc, 2012, 134: 3517-3523

125 Zhang T, Cheng F, Du J, Hu Y, Chen J. Efficiently enhancing oxygen reduction electrocatalytic activity of $\mathrm{MnO}_{2}$ using facile hydrogenation. Adv Energy Mater, doi: 10.1002/aenm.201400654

$126 \mathrm{Du}$ J, Zhang T, Cheng F, et al. Nonstoichiometric perovskite $\mathrm{CaMnO}_{3-\delta}$ for oxygen electrocatalysis with high activity. Inorg Chem, 2014, 53: 9106-9114

127 Du J, Pan Y, Zhang T, et al. Facile solvothermal synthesis of $\mathrm{CaMn}_{2} \mathrm{O}_{4}$ nanorods for electrochemical oxygen reduction. J Mater Chem, 2012, 22: 15812-15818

128 Chen Y, Freunberger SA, Peng Z, Fontaine O, Bruce PG. Charging a $\mathrm{Li}-\mathrm{O}_{2}$ battery using a redox mediator. Nat Chem, 2013, 5: 489-494

129 Sun D, Shen Y, Zhang W, et al. A solution-phase bifunctional catalyst for lithium-oxygen batteries. J Am Chem Soc, 2014, 136: 8941-8946

130 Lim HD, Song H, Kim J, et al. Superior rechargeability and efficiency of lithium-oxygen batteries: hierarchical air electrode architecture combined with a soluble catalyst. Angew Chem, 2014, 126: 4007-4012

131 Yu M, Ren X, Ma L, Wu Y. Integrating a redox-coupled dye-sensitized photoelectrode into a lithium-oxygen battery for photoassisted charging. Nat Commun, 2014, 5: 5111

$132 \mathrm{Hu} \mathrm{X}$, Han X, Hu Y, Cheng F, Chen J. $\varepsilon-\mathrm{MnO}_{2}$ nanostructures directly grown on $\mathrm{Ni}$ foam: a cathode catalyst for rechargeable $\mathrm{Li}-\mathrm{O}_{2}$ batteries. Nanoscale, 2014, 6: 3522-3525

133 Han X, Cheng F, Zhang T, et al. Hydrogenated uniform Pt clusters supported on porous $\mathrm{CaMnO}_{3}$ as a bifunctional electrocatalyst for enhanced oxygen reduction and evolution. Adv Mater, 2014, 26: 2047-2051

134 Han X, Hu Y, Yang J, Cheng F, Chen J. Porous perovskite $\mathrm{CaMnO}_{3}$ as an electrocatalyst for rechargeable $\mathrm{Li}_{-} \mathrm{O}_{2}$ batteries. Chem Commun, 2014, 50: 1497-1499

135 Han X, Cheng F, Chen $\mathrm{C}, \mathrm{Hu} \mathrm{Y}$, Chen J. Uniform $\mathrm{MnO}_{2}$ nanostructures supported on hierarchically porous carbon as efficient electrocatalysts for rechargeable $\mathrm{Li}-\mathrm{O}_{2}$ batteries. Nano Res, doi: 10.1007/ s12274-014-0604-y 
136 Hu Y, Han X, Cheng F, et al. Size effect of lithium peroxide on charging performance of $\mathrm{Li}_{-} \mathrm{O}_{2}$ batteries. Nanoscale, 2014, 6: 177180

Acknowledgements This work was supported by the State Key Project of Fundamental Research for Nanoscience and Nanotechnology (2011CB935900), the National Science Foundation of China (NSFC) (21322101, 21231005), and the Ministry of Education (B12015, IRT13R30, 113016A).
Author contributions Zhang K, Tao Z and Chen J designed the outline, investigated the references, and wrote the paper. $\mathrm{Hu} \mathrm{Z}$ contributed to the cathode part of LIBs. Chen J supervised and directed the review. All authors contributed to the general discussion.

Conflict of interest The authors declare that they have no conflict of interest.

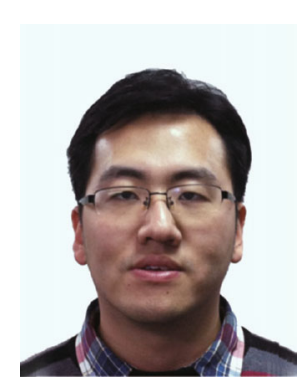

Kai Zhang was born in 1987. He received his BSc degree in materials chemistry from Nankai University (2010) and then joined the Key Laboratory of Advanced Energy Materials Chemistry (Ministry of Education) to study for his PhD degree. He is expecting to get his $\mathrm{PhD}$ in 2015 under the supervision of Professor Jun Chen. His research focuses on Liion batteries, Li-S batteries, and Na-ion batteries.

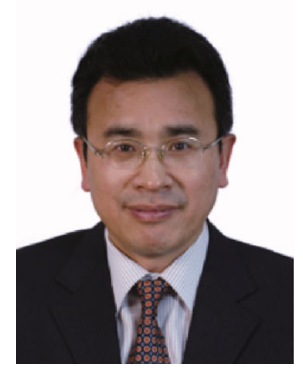

Jun Chen was born in 1967. He is a Cheung Kong Scholar Professor at the College of Chemistry, Nankai University, and Vice Chairman of the Chinese Society of Electrochemistry. He obtained his BSc and MSc degrees from Nankai University in 1989 and 1992, respectively, and his PhD from Wollongong University (Australia) in 1999. He held the NEDO fellowship at the National Institute of AIST Kansai Center (Japan) from 1999 to 2002. He has been working as the chair professor of energy chemistry at Nankai University since 2002. His research activity focuses on nanomaterials electrochemistry, batteries, fuel cells and solar cells.

中文摘要 作为电化学能源存储与转换的重要设备, 锂二次电池不断地改善着人类的生活. 为了满足人们对能量密度和功率密度不断 增长的需求, 急需为锂离子电池和锂硫二次电池开发高容量、可快速充放的电极材料, 寻找用于可充式锂空气电池的高活性的催化剂. 高容量要求电极材料具有高的电荷转移数和小的分子质量, 快速的电荷转移要求材料离子传输距离短、反应活性位点多, 而设计制备 纳米结构材料是改善电荷转移和离子电导率的有效手段. 本综述总结了最近在锂离子电池、锂硫二次电池和可充式锂空气电池中多电 子反应的研究进展, 详细地讨论了提高电池倍率和循环性能的方法. 可发生多电子反应的先进的锂电池将成为未来的研究重点. 